\title{
Colloids versus crystalloids for fluid resuscitation in critically ill patients (Review)
}

\author{
Roberts I, Alderson P, Bunn F, Chinnock P, Ker K, Schierhout G
}

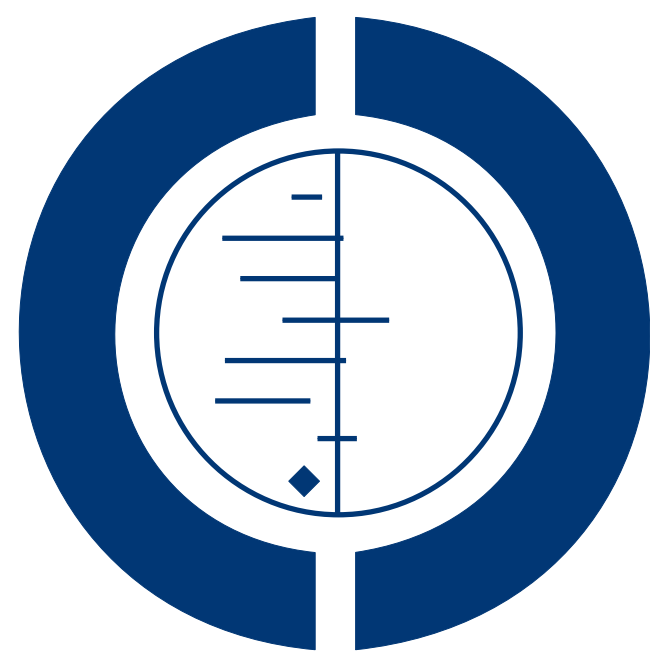

THE COCHRANE COLLABORATION $^{\circledR}$

This is a reprint of a Cochrane review, prepared and maintained by The Cochrane Collaboration and published in The Cochrane Library 2007, Issue 3

http://www.thecochranelibrary.com

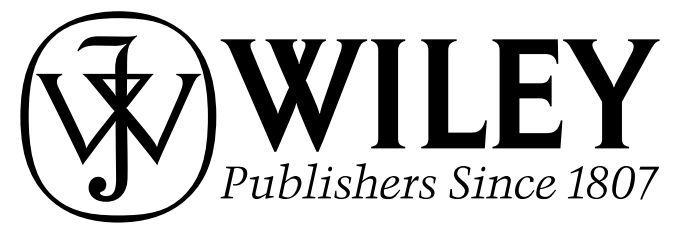

Colloids versus crystalloids for fluid resuscitation in critically ill patients (Review)

Copyright $\odot 2007$ The Cochrane Collaboration. Published by John Wiley \& Sons, Ltd 


\section{TABLE OF CONTENTS}

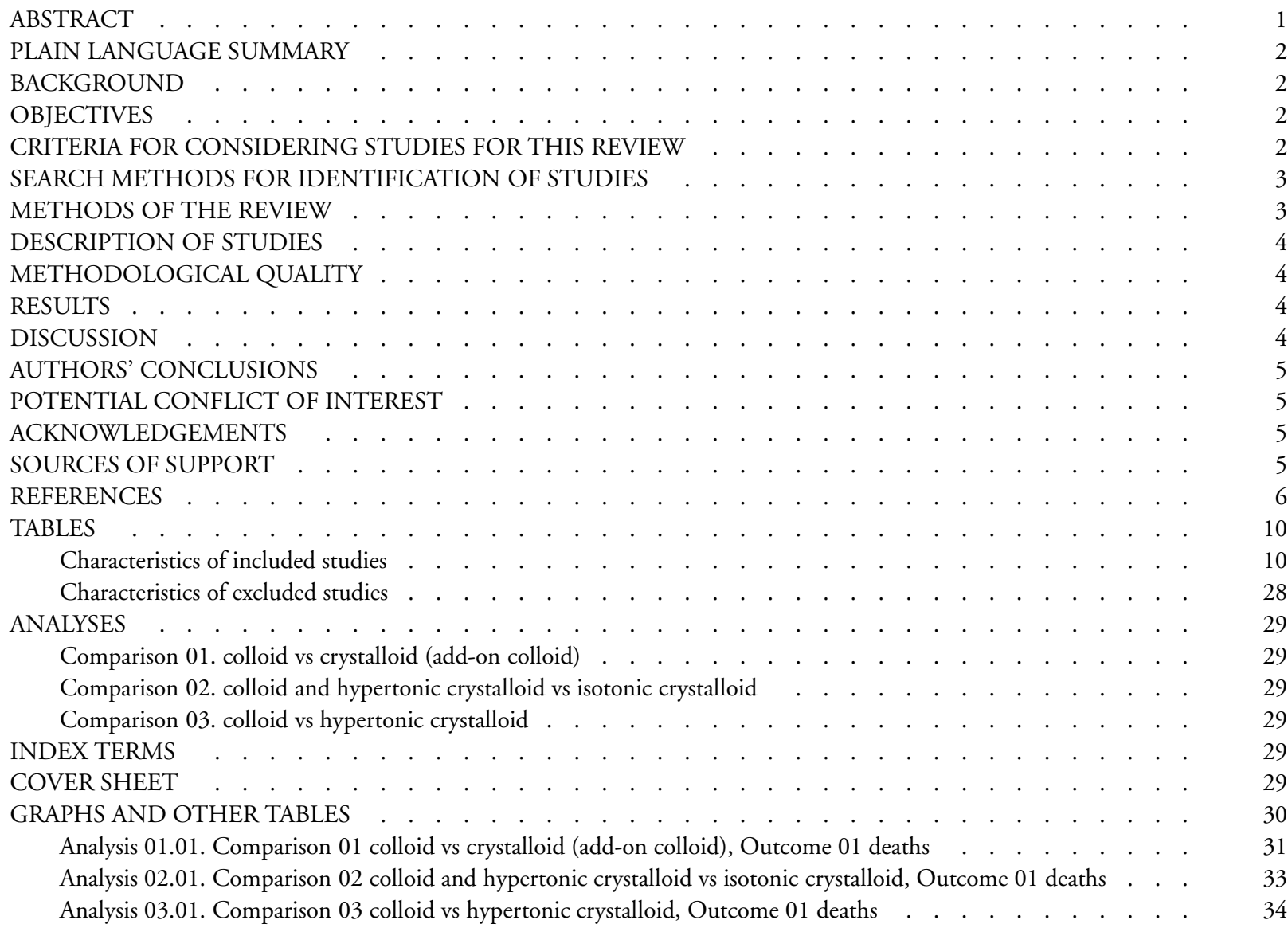




\title{
Colloids versus crystalloids for fluid resuscitation in critically ill patients (Review)
}

\author{
Roberts I, Alderson P, Bunn F, Chinnock P, Ker K, Schierhout G
}

This record should be cited as:

Roberts I, Alderson P, Bunn F, Chinnock P, Ker K, Schierhout G. Colloids versus crystalloids for fluid resuscitation in critically ill patients. Cochrane Database of Systematic Reviews 2004, Issue 4. Art. No.: CD000567. DOI: 10.1002/14651858.CD000567.pub2.

This version first published online: 18 October 2004 in Issue 4, 2004.

Date of most recent substantive amendment: 24 August 2004

\section{A B S T R A C T}

\section{Background}

Colloid solutions are widely used in fluid resuscitation of critically ill patients. There are several choices of colloid and there is ongoing debate about the relative effectiveness of colloids compared to crystalloid fluids.

\section{Objectives}

To assess the effects on mortality of colloids compared to crystalloids for fluid resuscitation in critically ill patients.

\section{Search strategy}

We searched the Injuries Group specialised register, Cochrane Controlled Trials Register, MEDLINE, EMBASE and BIDS Index to Scientific and Technical Proceedings, and checked reference lists of trials and review articles.

\section{Selection criteria}

All randomised and quasi-randomised trials of colloids compared to crystalloids, in patients requiring volume replacement. Cross-over trials and trials in pregnant women and neonates were excluded.

\section{Data collection and analysis}

Two reviewers independently extracted data and rated quality of allocation concealment. Trials with a 'double-intervention', such as those comparing colloid in hypertonic crystalloid to isotonic crystalloid, were analysed separately. The analysis was stratified according to colloid type and quality of allocation concealment.

\section{Main results}

Colloids compared to crystalloids

Albumin or plasma protein fraction. Nineteen trials reported data on mortality, including a total of 7576 patients. The pooled relative risk (RR) from these trials was 1.02 (95\% confidence interval [95\% CI] 0.93 to 1.11$)$. When the trial with poor quality allocation concealment was excluded, pooled RR was 1.01 (95\% CI 0.92 to 1.10$)$.

Hydroxyethyl starch. Ten trials compared hydroxyethyl starch with crystalloids, including a total of 374 randomised participants. The pooled RR was 1.16 (95\% CI 0.68 to 1.96$)$.

Modified gelatin. Seven trials compared modified gelatin with crystalloid, including a total of 346 randomised participants. The pooled RR was 0.54 (95\% CI 0.16 to 1.85$)$.

Dextran. Nine trials compared dextran with a crystalloid, including a total of 834 randomised participants. The pooled relative risk was RR 1.24 (95\% CI 0.94 to 1.65$)$.

Colloids in hypertonic crystalloid compared to isotonic crystalloid

Eight trials compared dextran in hypertonic crystalloid with isotonic crystalloid, including 1283 randomised participants. Pooled RR was 0.88 (95\% CI 0.74 to 1.05$)$.

Colloids versus crystalloids for fluid resuscitation in critically ill patients (Review)

Copyright $(2007$ The Cochrane Collaboration. Published by John Wiley \& Sons, Ltd 


\section{Authors' conclusions}

There is no evidence from randomised controlled trials that resuscitation with colloids reduces the risk of death, compared to resuscitation with crystalloids, in patients with trauma, burns or following surgery. As colloids are not associated with an improvement in survival, and as they are more expensive than crystalloids, it is hard to see how their continued use in these patients can be justified outside the context of randomised controlled trials.

\section{PLAIN LANGUAGESUMMARY}

No evidence that colloids are more effective than crystalloids in reducing mortality in people who are critically ill or injured

Trauma, burns or surgery can cause people to lose large amounts of blood. Fluid replacement, giving fluids intravenously (into a vein) to replace lost blood, is used to try to maintain blood pressure and reduce the risk of dying. Blood products, non-blood products or combinations are used, including colloid or crystalloid solutions. Colloids are increasingly used but they are more expensive than crystalloids. The review of trials found no evidence that colloids reduce the risk of dying compared with crystalloids.

\section{B A C K G R O U N D}

Fluid resuscitation for hypovolaemia is a mainstay of the medical management of critically ill patients, whether as a result of trauma, burns, major surgery or sepsis. Although recent studies (Bickell 1994) have suggested that the timing of volume replacement deserves careful consideration, when it comes to selecting the resuscitation fluid clinicians are faced with a range of options. At one level the choice is between a colloid or crystalloid solution. Colloids are widely used, having been recommended in a number of resuscitation guidelines and intensive care management algorithms (Vermeulen 1995; Armstrong 1994). The US Hospital Consortium Guidelines recommend that colloids are used in haemorrhagic shock prior to the availability of blood products, and in non-haemorrhagic shock following an initial crystalloid infusion. A 1995 survey of US academic health centres, however, found that the use of colloids far exceeded even the Hospital Consortium recommendations (Yim 1995). Surveys of burn care in the US (Fakhry 1995) and in Australia (Victorian DUAC 1991) found that the use of colloids for resuscitation varied without a set pattern. The choice of fluid has considerable cost implications. Volume replacement with colloids is considerably more expensive than with crystalloids. Clinical studies have shown that colloids and crystalloids have different effects on a range of important physiological parameters. Because of these differences, all-cause mortality is arguably the most clinically relevant outcome measure in randomised trials comparing the two fluid types. Although there have been previous meta-analyses of mortality in randomised trials comparing colloids and crystalloids (Velanovich 1989, Bisonni 1991), neither of these satisfy the criteria that have been proposed for scientific overviews (Oxman 1994), and they predate most of the trials that have been conducted using synthetic colloids, and hypertonic crystalloid solutions. The purpose of this review is to identify and synthesise all available unconfounded evidence of the effect on mortality in critically ill patients of colloids compared to crystalloids for volume replacement.

\section{O B JE C T IVES}

To determine the effects on mortality of using colloids compared to crystalloids, during fluid resuscitation in critically ill patients.

\section{CRITERIA FOR CONSIDERING STUDIES FOR THIS REVIEW}

\section{Types of studies}

Controlled trials in which participants were randomised to treatment groups (colloid or control) on the basis of random or quasirandom allocation. As the comparison between fluid type was in terms of effects on mortality, randomised cross-over trials were excluded.

\section{Types of participants}

Critically ill patients (excluding neonates) who required volume replacement. Types of participants included were those who were critically ill as a result of trauma, burns, were undergoing surgery, or had other critical conditions such as complications of sepsis.

Preoperative elective surgical patients were excluded.

\section{Types of intervention}

The colloids considered were Dextran 70, hydroxyethyl starches, modified gelatins, albumin or plasma protein fraction.

There is overlap between albumin given for volume replacement and albumin given as a nutritional supplement, and many patients with a critical illness have low serum albumin. Where the trial was of total parenteral nutrition with or without albumin, it was excluded. We included trials where the albumin was given as part 
of volume replacement guided by colloid osmotic pressure or albumin levels.

The control group received crystalloid (isotonic or hypertonic) for fluid replacement. Trials where both groups received blood were included.

Trials of fluids used for other purposes were excluded. For example, trials of pre-loading in preparation for elective surgery, and trials in patients undergoing fluid loading before cardiopulmonary bypass, were excluded.

\section{Types of outcome measures}

The principal outcome measure was mortality from all causes, assessed at the end of the follow-up period scheduled for each trial.

\section{SEARCH METHODSFOR IDENTIFICATIONOFSTUDIES}

See: methods used in reviews.

MEDLINE: latest search, September 2002.

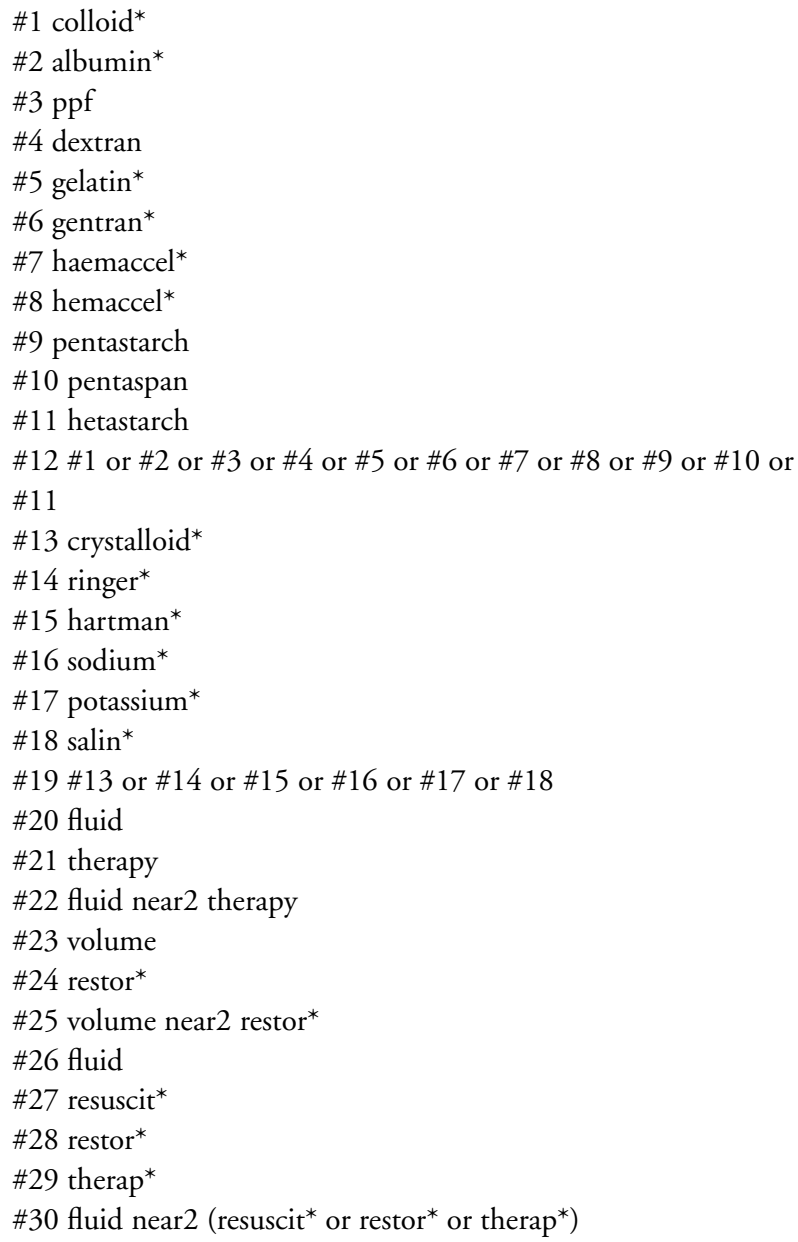

\#31 plasma \#32 substit* \#33 fluid \#34 volume \#35 substit* \#36 replace*

\#37 (plasma near2 substit*) or ((fluid or volume) near2 (substit* or replace $\left.{ }^{*}\right)$ )

$\# 38$ \#22 or \#25 or \#30 or \#37

$\# 39 \# 12$ and \#19 and \#38

\#40 controlled

\#41 clinical

\#42 trial*

$\# 43$ controlled clinical trial*

\#44 randomi*

\#45 controlled

\#46 trial*

\#47 randomi* controlled trial*

\#48 explode research design/ all subheadings

\#49 double

\#50 blind

\#51 double blind

\#52 meta

\#53 analysis

\#54 metaanalysis

\#55 meta analysis or metaanalysis

\#56 clinical trial in pt

$\# 57$ \#43 or \#47 or \#48 or \#51 or \#55 or \#56

\#58 \#39 and \#57

The reference lists of all identified trials and review articles were checked, and we contacted the trialists, to ask if any studies had been missed.

The update of the Injuries Group review on Human albumin (Albumin 2004) also found new papers that were relevant for this review. The major SAFE trial (SAFE 2004) was published after the search was done but, the reviewers being aware of its publication, it was also considered and was found to meet the inclusion criteria.

Full details of the search strategies used can be obtained from the Injuries Group Trials Search Co-ordinator.

\section{METHODS OF THE REVIEW}

Allocation concealment was scored as described by Schulz (Schulz 1995). In particular, the presence of solutions in identical containers was only taken to mean adequate concealment if the fluid containers were used sequentially.

Information on blinding and loss to follow-up was collected but not scored.

Colloids versus crystalloids for fluid resuscitation in critically ill patients (Review)

Copyright $(2007$ The Cochrane Collaboration. Published by John Wiley \& Sons, Ltd 
As a result of comments on the previous version of this review, trials were stratified by type of fluid rather than type of original injury.

Relative risk (RRs) and 95\% confidence interval (95\% CI) were calculated for each study using a fixed effects model. Each comparison was then inspected visually for evidence of heterogeneity and a chi-squared test performed. If there was no evidence of heterogeneity (visually or with a $p$ value $<0.1$ ) the trials were pooled within each type of fluid, but not combined between type of fluid.

Trials with allocation concealment judged as inadequate were then excluded and the calculations repeated.

\section{DESCRIPTION OF STUDIES}

There were 53 trials meeting the inclusion criteria for study design, participants and interventions. We were able to obtain data on deaths for 46 of these. Details of the remaining trials are also reported in the Table of Included Studies for completeness.

Reasons for exclusion of trials were: the use of a cross-over design, testing a resuscitation algorithm, giving the control group oral fluids, the intervention being directed to the maintenance of serum albumin levels, for haemodilution, for fluid loading and for the reduction of intracranial pressure (see Table of Excluded Studies).

Of the 46 randomised controlled trials with data on deaths, the quality of allocation concealment was adequate in six trials and unclear in most of the others.

There were 42 comparisons of colloids and crystalloids (add-on colloid), nine comparisons of colloid in hypertonic crystalloid with isotonic crystalloid, and three comparisons of colloid with hypertonic crystalloid (see Table of Included Studies).

\section{METHODOLOGICAL QUALITY}

In general, the design of studies was not well reported. This is reflected in the number of unclear scores given for allocation concealment. We also collected information on blinding and loss to follow-up. Blinding was not well reported and loss to follow-up was generally small. The characteristics for each trial are listed in the Table of Included studies.

\section{R E S U L T S}

\section{Colloids compared to crystalloids}

Albumin or plasma protein fraction

Twenty trials reported data on mortality, including a total of 7576 patients. The pooled RR from these trials was 1.02 (95\% CI 0.93 to 1.11$)$. When the one trial with poor quality allocation concealment (Lucas 1978) was excluded, the pooled RR was 1.01 (95\% CI 0.92 to 1.01$)$.

Hydroxyethyl starch

Ten trials compared hydroxyethyl starch with crystalloids, including a total of 374 randomised participants. The pooled RR was 1.16 (95\% CI 0.68 to 1.96$)$.

\section{Modified gelatin}

Seven trials compared modified gelatin with crystalloid, including a total of 346 randomised participants. The pooled RR was 0.54 (95\% CI 0.16 to 1.85 ).

\section{Dextran}

Nine trials compared dextran with a crystalloid, including a total of 834 randomised participants. The pooled RR was 1.24 (95\% CI 0.94 to 1.65$)$.

Colloids in hypertonic crystalloid compared to isotonic crystalloid

One trial compared albumin and hypertonic saline with isotonic crystalloid. Its relative risk of death was 0.50 (0.06 to 4.33).

Eight trials compared dextran in hypertonic crystalloid with isotonic crystalloid, including 1283 randomised participants. The pooled RR was 0.88 (0.74 to 1.05 ).

Colloids in isotonic crystalloid compared to hypertonic crystalloid

Three trials compared colloids in isotonic crystalloid with hypertonic crystalloid. In two of these, where the colloid was either gelatin or starch, there were no deaths in either group. In the remaining trial, with 38 participants, there was a relative risk of death of 7.00 (0.39 to 126.93) for use of colloid, based on three deaths in the treatment group and none in the control group.

\section{I S C US S I O N}

This systematic review synthesises the evidence from randomised controlled trials comparing colloid and crystalloid fluid resuscitation across a wide variety of clinical conditions. The review has been updated and extensively revised to take into account the comments made since it was first published. In particular, several commentators pointed out that it is inappropriate to combine effect estimates from studies of different colloids. For example, it was argued that large molecular weight colloids such as hydroxyethyl starch may be better retained in the vascular compartment than albumin and gelatins, and would therefore be more likely to show a favourable effect on mortality (Gosling 1998). In response to these concerns, the review has been stratified by type of colloid. However, the pooled relative risks fail to show a mortality benefit for resuscitation with any type of colloid. 
There was a trend towards a favourable effect on mortality for colloids in hypertonic crystalloid, compared to isotonic crystalloids. Nevertheless, the results are compatible with the play of chance.

Common to all meta-analyses, this systematic review may have included studies whose interventions and patient characteristics are sufficiently incomparable that the calculation of a summary effect measure may be questioned. The resuscitation regimen differed between trials. Some trials randomised participants to an initial quantity of colloid or crystalloid, and then proceeded with some form of standard resuscitation for all participants. Other trials resuscitated with the allocated fluid to pre-determined end-points, either resuscitation end-points, or in the case of trauma, until corrective surgery. In addition, the type of colloid or crystalloid, the concentration, and the protocol to determine the quantity of fluid varied. Despite these differences, all participants were in need of volume replacement, and we believe that this variation in the intervention would have an impact on the size of the effect, rather than on its direction.

As regards the effects of albumin versus crystalloid, most of the information (as indicated by the weighting in the meta-analysis) was provided by the SAFE trial. The SAFE trial used central randomisation with a minimisation algorithm to ensure balance on known potential confounders. Blinding was assured through the use of specially designed masking cartons and specially designed and manufactured administration sets. The authors report that the effectiveness of the blinding was confirmed in a formal study before the trial was initiated. In brief, this was a well- conducted, high-quality trial. There were 726 deaths $(20.9 \%)$ in the albumintreated group and 729 deaths $(21.1 \%)$ in the saline-treated group (RR of death $0.99 ; 95 \%$ CI 0.91 to 1.09 ). Although even this large trial was unable to confirm or refute the possibility of a modest benefit or harm from albumin, it has provided some reassurance that any hazard from albumin, if indeed there is any, is unlikely to be as extreme as was suggested by the results from the previously published (now here updated) meta-analysis of much smaller trials. The pooled relative risk for death with albumin in this updated meta-analysis is now 1.02 (0.93 to 1.11). It is important to note that the effect estimate from the SAFE trial is entirely consistent with the results of previous trials of albumin in hypovolaemia and there is no significant heterogeneity $\left(\mathrm{I}^{2}=0 \%, \mathrm{p}=0.46\right)$.

The results of this updated meta-analysis have important policy implications. There is still no evidence that colloids are superior to crystalloids as a treatment for intravascular volume resuscitation in critically ill patients. Importantly, the SAFE trial also provided no evidence of any other clinical advantages from using albumin. It also debunked the belief, from pathophysiological inference, that very large volumes of crystalloid must be administered to reach the same resuscitation end-points as can be achieved using much smaller volumes of colloid. In the SAFE trial, the ratio of albumin administered to saline administered was approximately 1:1.4. Colloids, in particular albumin, are considerably more expensive than crystalloids, and albumin is a blood product and so carries at least a theoretical infectious disease risk. The economic opportunity cost of on-going colloid use, particularly albumin use, is likely to be considerable and for this reason its on-going use in this context is unjustified.

\section{AUTHORS' CONCLUSIONS}

\section{Implications for practice}

There is no evidence from randomised controlled trials that resuscitation with colloids, instead of crystalloids, reduces the risk of death in patients with trauma, burns or following surgery. As colloids are not associated with an improvement in survival, and further, colloids are considerably more expensive than crystalloids, it is hard to see how their continued use outside the context of randomised controlled trials in subsets of patients of particular concern, can be justified.

\section{Implications for research}

Future trials may need to concentrate on specific sub-groups of patients to identify people who may benefit from colloids rather than crystalloids.

\section{POTENTIALCONFLICTOF I N T E R E S T}

None known.

\section{ACKNOWLEDGEMENTS}

We would like to acknowledge the Intensive Care National Audit and Research Network in London, for assistance with identification of trials for this review.

\section{SOURCES OF SUPPORT}

\section{External sources of support}

- NHS R\&D Programme: Mother and Child Health UK

Internal sources of support

- Institute of Child Health, University of London UK

- UK Cochrane Centre, NHS R\&D Programme UK 


\section{R E F E R E N C E S}

\section{References to studies included in this review \\ Boldt 1986 \{published data only\}}

Boldt J, von Bormann B, Kling D, Borner U, Mulch J, Hempelmann G. Volume replacement with a new hydroxyethyl starch preparation (3 percent HES 200/0.5) in heart surgery [Volumenersatz mit einem neuen hydroxyathylstarke - praparat (3\% HAS 200/0.5) in der herzchirurgie]. Infusionsther Klin Ernahr 1986;13(3):145-51.

Boldt 1993 \{published data only\}

Boldt J, Knothe C, Zickmann B, Andres P, Dapper F, Hempelmann $\mathrm{G}$. Influence of different intravascular volume therapies on platelet function in patients undergoing cardiopulmonary bypass. Anesthesia and Analgesia 1993;76(6):1185-90.

Boldt 2001 \{published data only\}

Boldt J, Suttner S, Huttner I, Kumle B, Piper S, Krumholz W. Are costs of a crystalloid-based volume replacement regimen lower than of a colloid-based volume replacement stategy. Infusion Therapy and Transfusion Medicine 2001;28:144-9.

Boutros 1979 \{published data only\}

Boutros AR, Ruess R, Olson L, Hoyt JL, Baker WH. Comparison of hemodynamic, pulmonary, and renal effects of use of three types of fluids after major surgical procedures on the abdominal aorta. Critical Care Medicine 1979;7(1):9-13.

Bowser-Wallace 1986 \{published data only\} Bowser-Wallace BH, Caldwell FT Jr. A prospective analysis of hypertonic lactated saline v. Ringer's lactate-colloid for the resuscitation of severely burned children. Burns 1986;12(6):402-9.

Chavez-Negrete 1991 \{published data only\}

Chavez-Negrete A, Lajluf Cruz S, Frati Munari A, Perches A, Argulero R. Treatment of hemorrhagic shock with intraosseus or intravenous infusion of hypertonic saline eextran solution. European Surgical Research 1991;23(2):123-9.

Dawidson 1991 \{published data only\}

Dawidson IJ, Willms CD, Sandor ZF, Coorpender LL, Reisch JS, Fry WJ. Ringer's lactate with or without 3\% dextran-60 as volume expanders during abdominal aortic surgery. Critical Care Medicine 1991;19(1):36-42.

Dehne 2001 \{published data only\} Dehne MG, Muhling J, Sablotzki A, Dehn K-L, Sucke N, Hempelmann G. Hydroxyethyl starch (HES) does not directly affect renal function in patients with no prior renal impairment. Journal of Clinical Anaesthesia 2001;13(2):103-11.

Eleftheriadis 1995 \{published data only\} Eleftheriadis S, Sedemund-Adib B, Klotz K-F, Hubner N, Kuppe H. Volume Replacement After Cardiac Surgery: Comparison Of Ringer, HES 6\% And Gelatine 3.5\%. Intensive Care Medicine 1995;21 (suppl 1):S216.

Ernest 1999 \{published data only\} Ernest D, Belzberg A, Dodek P. Distribution of normal saline and 5\% albumin infusions in septic patients. Critical Care Medicine 1999;27 (1):46-50.

Evans 1996 \{published and unpublished data\}

Evans PA, Garnett M, Boffard K, Kirkman E, Jacobson BF. Evaluation of the effect of colloid (Haemaccel) on the bleeding time in the trauma patient. Journal of the Royal Society of Medicine 1996;89(2): $101-4$.

Gallagher 1985 \{published data only\}

Gallagher JD, Moore RA, Kerns D, Jose AB, Botros SB, Flicker S, Naidech H, Clark DL. Effects of colloid or crystalloid administration on pulmonary extravascular water in the postoperative period after coronary artery bypass grafting. Anesthesia and Analgesia 1985;64(8): 753-8.

Goodwin 1983 \{published data only\}

Goodwin CW, Dorethy J, Lam V, Pruitt BA Jr. Randomized trial of efficacy of crystalloid and colloid resuscitation on hemodynamic response and lung water following thermal injury. Annals of Surgery 1983;197(5):520-31

Grundmann 1982 \{published data only\}

Grundmann R, Heistermann S. Postoperative albumin infusion therapy based on colloid osmotic pressure. A prospectively randomized trial. Archives of Surgery 1985;120(8):911-5.

Grundmann R, Meyer $\mathrm{H}$. The significance of colloid osmotic pressure measurement after crystalloid and colloid infusions. Intensive Care Medicine 1982;8(4):179-86.

Hall 1978 \{published data only\}

Hall K, Sorensen B. The treatment of burn shock. Scandinavian Journal of Plastic and Reconstructive Surgery 1973;7:67-73.

Hall K, Sorensen B. The treatment of burns shock. In: VrabecR, KonickovaL, MoserovaJ editor(s). Basic problems in burns. Berlin: Springer-Verlag, 1975.

Hall KV, Sorensen B. The treatment of burn shock: results of a 5 -year randomized, controlled clinical trial of Dextran $70 \mathrm{v}$ Ringer lactate solution. Burns 1978;5(1):107-12.

Hartmann 1993 \{published data only\}

Hartmann M, Jonsson K, Zederfeldt B. Effects of dextran and crystalloids on subcutaneous oxygen tension and collagen accumulation. A randomized study in surgical patients. European Surgical Research 1993;25:270-7.

Jelenko 1978 \{published data only\}

Jelenko C 3rd. Fluid therapy and the HALFD method. Journal of Trauma 1979;19(11 Suppl):866-7.

Jelenko C 3rd, Solenberger RI, Wheeler ML, Callaway BD. Shock and resuscitation. III. Accurate refractometric COP determinations in hypovolemia treated with HALFD. JACEP 1979;8(7):253-6.

Jelenko C 3rd, Wheeler ML, Callaway BD, Divilio LT, Bucklen KR, Holdredge TD. Shock and resuscitation. II: Volume repletion with minimal edema using the "HALFD"(Hypertonic Albuminated Fluid Demand) regimen. JACEP 1978;7(9):326-33.

Jelenko C 3rd, Williams JB, Wheeler ML, et al.Studies in shock and resuscitation, I: use of a hypertonic, albumin-containing, fluid demand regimen (HALFD) in resuscitation. Crit Care Med 1979;7 (4):157-67.

Karanko 1987 \{published data only\}

Karanko M, Klossner J, Laksonen V. Restoration of volume by crystalloid versus colloid after coronary artery bypass: haemodynamics, 
lung water, oxygenation and outcome. Critical Care Medicine 1987; 15:559-66.

Lang 2001 \{published data only\}

Lang K, Boldt J, Suttner S, Haisch G. Colloids versus crystalloids and tissue oxygen tension in patients undergoing major abdominal surgery. Anesthesia and Analgesia 2001;93(2):405-9.

Ley 1990 \{published data only\}

Ley SJ, Miller K, Skov P. Crystalloid versus colloid fluid therapy after cardiac surgery. Clinical Studies in Cardiac Care 1990;19(1):31-40.

Lowe 1977 \{published data only\}

Lowe RJ, Moss GS, Jilek J, Levine HD. Crystalloid versus colloid in the etiology of pulmonary failure after trauma - a randomized trial in man. Critical Care Medicine 1979;7(3):107-12.

Lowe RJ, Moss GS, Jilek J, Levine HD. Crystalloid vs colloid in the etiology of pulmonary failure after trauma: a randomized trial in man. Surgery 1977;1(6):676-83.

Moss GS, Lowe RJ, Jilek J, Levine HD. Colloid or crystalloid in the resuscitation of hemorrhagic shock: a controlled clinical trial. Surgery 1981;89(4):434-8.

Lucas 1978 \{published data only\}

Clift DR, Lucas CE, Ledgerwood AM, Sardesai V, Kithier K, Grabow D. The effect of albumin resuscitation for shock on the immune response to tetanus toxoid. Journal of Surgical Research 1982;32:44952.

Johnson SD, Lucas CE, Gerrick SJ, Ledgerwood AM, Higgins. Altered coagulation after albumin supplements for treatment of oligaemic shock. Archives of Surgery 1979;114:379-83.

Lucas CE, Bouwman DL, Ledgerwood AM, Higgins R. Differential serum protein changes following supplemental albumin resuscitation for hypovolemic shock. Journal of Trauma 1980;20(1):47-51.

Lucas CE, Weaver D, Higgins RF, Ledgerwood AM, Johnson SD, Bouwman DL. Effects of albumin versus non-albumin resuscitation on plasma volume and renal excretory function. Journal of Trauma 1978;18:565-70.

Weaver DW, Ledgerwood AM, Lucas CE, Higgins R, Bouwman DL, Johnson SD. Pulmonary effects of albumin resuscitation for severe hypovolaemic shock. Archives of Surgery 1978;113:387-92.

Mattox 1991 \{published data only\}

Maningas PA, Mattox KL, Pepe PE, Jones RL, Feliciano DV, Burch JM. Hypertonic saline-dextran solutions for the prehospital management of traumatic hypotension. American Journal of Surgery 1989; 157(5):528-33.

Mattox KL, Maningas PA, Moore EE, et al.Prehospital hypertonic saline/dextran infusion for post-traumatic hypotension. The U.S.A. Multicenter Trial. Annals of Surgery 1991;213(5):482-91.

Mazher 1998 \{published data only\}

Mazher R, Samenesco A, Royston D, Rees A. Cardiopulmonary effects of $7.2 \%$ saline solution compared with gelatin infusion in the early postoperative period after coronary artery bypass grafting. Journal of Thoracic and Cardiovascular Surgery 1998;115(1):178-87.

McNulty 1993 \{published data only\}

McNulty SE, Sharkey SJ, Asam B, Lee JH. Evaluation of STATCRIT Hematocrit Determination in comparison to Coulter and
Centrifuge: the effects of isotonic hemodilution and albumin administration. Anesthesia and Analgesia 1993;76:830-4.

Metildi 1984 \{published data only\} Metildi LA, Shackford SR, Virgilio RW, Peters RM. Crystalloid versus colloid in fluid resuscitation of patients with severe pulmonary insufficiency. Surgery, Gynecology and Obstetrics 1984;158(3):207-12.

Modig 1983 \{published data only\}

Modig J. Advantages of dextran 70 over Ringer acetate solution in shock treatment and in prevention of adult respiratory distress syndrome. A randomized study in man after traumatic-haemorrhagic shock. Resuscitation 1983;10(4):219-26.

Modig J. Effectiveness of dextran 70 versus Ringer's acetate in traumatic shock and adult respiratory distress syndrome. Critical Care Medicine 1986;14(5):454-7.

Nagy 1993 \{published data only\}

Nagy KK, Davis J, Duda J, Fildes J, Roberts R, Barrett J. A comparison of pentastarch and lactated Ringer's solution in the resuscitation of patients with hemorrhagic shock. Circulatory Shock 1993;40(4): 289-94.

Ngo 2001 \{published data only\}

Ngo NT, Cao XT, Kneen R, Wills B, Nguyen VM, Nguyen TQ, Chu VT, Nguyen TT, Simpson JA, Solomon T, White NJ, Farrar J. Acute management of dengue shock syndrome: a randomised double-blind comparison of 4 intravenous fluid regimes in the first hour. Clinical Infectious Diseases 2001;32(2):204-13.

Nielsen 1985 \{published data only\}

Nielsen OM, Engell HC. Extracellular fluid volume and distribution in relation to changes in plasma colloid osmotic pressure after major surgery. A Randomised Study. Acta Chir Scand 1985;151:221-5.

Pockaj 1994 \{published data only\}

Pockaj BA, Yang JC, Lotze MT, et al.A prospective randomized trial evaluating colloid versus crystalloid resuscitation in the treatment of the vascular leak syndrome associated with interleukin-2 therapy. Journal of Immunotherapy 1994;15(1):22-8.

Prien 1990 \{published data only\}

Prein T, Backhaus N, Pelster F, et al.Effect of intraoperative fluid adminstration and colloid osmotic pressure on the formation of intestinal edema during gastrointestinal surgery. Journal of Clinical Anesthesia 1990;2:317-23.

Rackow 1983 \{published data only\}

Haupt, MT, Rackow, EC. Colloid osmotic pressure and fluid resuscitation with hetastarch, albumin, and saline solutions. Critical Care Medicine 1982;10(3):159-62.

Kaufman BS, Rackow EC, Falk JL. Fluid resuscitation in circulatory shock. Colloids versus crystalloids. Current Studies in Hematology and Blood Transfusion 1986;53:186-98.

Rackow EC, Falk JL, Fein IA, et al.Fluid resuscitation in circulatory shock: a comparison of the cardiorespiratory effects of albumin, hetastarch, and saline solutions in patients with hypovolemic and septic shock. Crit Care Medicine 1983;11(11):839-50.

\section{Rocha e Silva 1994}

Rocha e Silva M, Poli de Figueiredo LF. Hypertonic-hyperoncotic saline solution for the treatment of post-traumatic hypotension in 
the emergency room. The Brazilian multi-center trial. SALT 6. International Conference on Hypertonic Resuscitation, Teton Village. June 2-3 1994.

SAFE 2004 \{published data only\}

The SAFE Study Investigators. A comparison of albumin and saline for fluid resuscitation in the intensive care unit. New England Journal of Medicine 2004;350(22):2247-56.

Shah 1977 \{published data only\}

Shah DM, Broner BD, Dutton RE, Newell JC, Powers SR. Cardiac output and pulmonary wedge pressure. Use for evaluation of fluid replacement in trauma patients. Archives of Surgery 1977;112:11618.

Shires 1983 \{published data only\}

Shires G, Peitzman A, Albert S, Illner H, Silane M, Perry M, et al.Response of extravascular lung water to intraoperative fluids. Annals of Surgery 1983;197:515-8.

Sirieix 1999 \{published data only\}

*Sirieix D, Hongnat J-M, Delayance S, D'Attellis N, Vicaut E, Berribi A, et al.Comparison of the acute haemodynamic effects of hypertonic or colloid infusions immediately after mitral valve repair. Critical Care Medicine 1999;27:2159-65.

Skillman 1975 \{published data only\}

Skillman JJ, Restall DS, Salzman EW. Randomized trial of albumin vs. electrolyte solutions during abdominal aortic operations. Surgery 1975;78(3):291-303.

Tollofsrud 1995 \{published data only\}

Tollofsrud S, Svennevig JL, Breivik H, et al.Fluid balance and pulmonary functions during and after coronary artery bypass surgery: Ringer's acetate compared with dextran, polygeline, or albumin. Acta Anaesthesiologica Scandinavica 1995;39:671-7.

Tollofsrud 1998 \{published data only\}

Tollofsrud S, Noddeland H. Hypertonic saline and dextran after coronary artery surgery mobilises fluid excess and improves cardiorespiratory functions. Acta Anaesthesiologica Scandinavica 1998;42:154-61.

Vassar 1990 \{published data only\}

Vassar MJ, Perry CA, Holcroft JW. Analysis of potential risks associated with $7.5 \%$ sodium chloride resuscitation of traumatic shock. Archives of Surgery 1990;125(10):1309-15.

Vassar 1991 \{published data only\}

Holcroft JW, Vassar MJ, Turner JE, Derlet RW, Kramer GC. 3\% $\mathrm{NaCl}$ and $7.5 \% \mathrm{NaCl} /$ dextran 70 in the resuscitation of severely injured patients. Annals of Surgery 1987;206(3):279-88.

Vassar MJ, Perry CA, Gannaway WL, Holcroft JW. 7.5\% sodium chloride/dextran for resuscitation of trauma patients undergoing helicopter transport. Archives of Surgery 1991;126(9):1065-72.

Vassar 1993a \{published data only\}

Vassar MJ, Perry CA, Holcroft JW. Prehospital resuscitation of hypotensive trauma patients with $7.5 \% \mathrm{NaCl}$ versus $7.5 \% \mathrm{NaCl}$ with added dextran: a controlled trial. Journal of Trauma 1993;34(5):62232.

Vassar 1993b \{published data only\}

Vassar MJ, Fischer RP, O’Brien PE, et al.A multicenter trial for resuscitation of injured patients with $7.5 \%$ sodium chloride. The effect of added dextran 70. The Multicenter Group for the Study of
Hypertonic Saline in Trauma Patients. Archives of Surgery 1993;128 (9):1003-11.

Virgilio 1979 \{published data only\}

Virgilio RW, Rice CL, Smith DE, et al.Crystalloid vs. colloid resuscitation: is one better? A randomized clinical study. Surgery 1979;85 (2):129-39.

Wahba 1996 \{published data only\}

Wahba A, Sendtner E, Strotzer M, Wild K, Birnbaum DE. Fluid therapy with Ringer's solution versus Haemaccel following coronary artery bypass surgery. Acta Anaesthesiologica Scandinavica 1996;40: $1227-33$

Woittiez 1997 \{published and unpublished data\} Hondebrink Y, Jeekel L, Oude Nijhuis J, Woittiez AJJ. Restoration of colloid osmotic pressure in hypoalbuminaemic patients. Intensive Care Medicine 1997;23(supp 1):S184.

Wu 2001 \{published data only\} Wu J, Huang M, Tang G, Kao W, Shih H, Su C, Lee C. Hemodynamic response of modified fluid gelatin compared with lactated ringer's solution for volume expansion in emergency resuscitation of hypovolemic shock patients: preliminary report of a prospective, randomized trial. World Journal of Surgery 2001;25(5):598-602.

Younes 1992 \{published data only\}

Younes RN, Aun F, Accioly CQ, Casale LP, Szajnbok I, Birolini D. Hypertonic solutions in the treatment of hypovolemic shock: a prospective, randomized study in patients admitted to the emergency room. Surgery 1992;111(4):380-5.

Younes 1994 \{published data only\}

Younes R, Aun F, Ching C, Goldenberg D, Franco M, Miura F, et al.Prognostic factors to predict outcome following the administration of hypertonic/hyperoncotic solution in hypovolaemic patients. Shock 1997;7:79-83.

Younes RN, Aun F, Ching C, et al.Prognosis following the administration of hypertonic/hyperoncotic solutions in hypovolemic patients. SALT 6. International Conference on Hypertonic Resuscitation. Teton Village. June 2-3 1994.

Younes 1998 \{published data only\}

Younes R, Yin K, Amino C, Itinoshe M, Rocha e Silva M, Birolini D. Use of pentastarch solution in the treatment of patients with hemorrhagic hypovolemia: randomized phase II study in the emergency room. World Journal of Surgery 1998;22:2-5..

Zetterstrom 1981a \{published data only\}

Zetterstrom $\mathrm{H}$, Hedstrand U. Albumin treatment following major surgery. I. Effects on plasma oncotic pressure, renal function and peripheral oedema. Acta Anaesthesiologica Scandinavica 1981;25:12532.

Zetterstrom 1981b \{published data only\}

Zetterstrom H. Albumin treatment following major surgery. II. Effects on postoperative lung function and circulatory adaptation. Acta Anaesthesiologica Scandinavica 1981;25:133-41.

\section{References to studies excluded from this review Artru 1989}

Artru F, Philippon B, Flachaire E, et al.A controlled study of Dextran 40: effect on cerebral blood flow and metabolic rates in acute head trauma. Intensive Care Medicine 1989;15(8):499-504. 


\section{Bocanegra 1966}

Bocanegra M, Hinostroza F, Kefalides NA, Markley K, Rosenthal SM. A long-term study of early fluid therapy in severely burned adults. 3. Simultaneous comparison of saline solution alone or combined with plasma. Journal of the American Medical Association 1966; 195(4):268-74.

\section{Boldt 1996}

Boldt J, Heesen M, Padberg W, Martin K, Hempelmann G. The influence of volume therapy and pentoxifylline infusion on circulating adhesion molecules in trauma patients. Anaesthesia 1996;51:529-35.

\section{Bothner 1998}

Bothner U, Georgieff M, Vogt N. Assessment of the safety and tolerance of $6 \%$ hydroxyethyl starch $(200 / 0.5)$ solution: a randomized, controlled epidemiology study. Anesthesia and analgesia 1998; 86:850-5.

\section{Breheme 1993}

Brehme S, Keysser G, Turowski A, Schmidt HH. Hemorheologic effects of hydroxyethyl starch $200 / 0.5$, dextran 40 , oxypolygelatine and full electrolyte solution over 48 hours [Hamorheologische Wirkungen von Hydroxyathylstarke 200/0,5, Dextran 40, Oxypolygelatine und Vollelektrolytlosung uber 48 Stunden]. Z-Gesamte-Inn-Med 1993;48(10):506-10.

\section{Golub 1994}

Golub R, Sorrento JJ Jr, Cantu R Jr, Nierman DM, Moideen A, Stein HD. Efficacy of albumin supplementation in the surgical intensive care unit: a prospective, randomized study. Critical Care Medicine 1994;22(4):613-9.

Goslinga 1992

Goslinga H, Eijzenbach V, Heuvelmans JH, van de Nes JC, Kurk RM, Bezemer PD. [Individualized hemodilution in acute brain infarct using a $20 \%$ albumin solution and physiological saline solution]. Ned Tijdschr Geneeskd 1992;136(49):2422-8.

Goslinga H, Eijzenbach V, Heuvelmans JH, et al.Custom-tailored hemodilution with albumin and crystalloids in acute ischemic stroke. Stroke 1992;23(2):181-8.

Goslinga H, Heuvelmans JH, Schmid Schonbein H. Hemodilution and rehydration in acute ischemic stroke. A preliminary report on the Amsterdam Stroke Study. Acta Med Austriaca 1991;18(Suppl 1): $41-4$.

\section{Greenhalgh 1995}

Greenhalgh DG, Housinger TA, Kagan RJ, et al.Maintenance of serum albumin levels in pediatric burn patients: a prospective, randomized trial. Journal of Trauma 1995;39(1):67-73; discussion 734.

\section{Hauser 1980}

Hauser CJ, Shoemaker WC Turpin I, Goldberg SJ. Oxygen transport response to colloids and crystalloids in critically ill surgical patients. Surgery 1980;150(6):811-16.

\section{Lagonidis 1995}

Lagonidis D, Magder S. Acute volume loading with colloid vs. crystalloid after coronary artery bypass. Intensive Care Medicine 1992;18: (suppl 2):S225.

\section{Marhofer 1999}

Marhofer P, Faryniak B, Oismuller C, Koinig H, Kapral S, Mayer N. Cardiovascular efffects of $6 \%$ hetastarch and lactated Ringer's solu- tion during spinal anaesthesia. Regional Anesthesia and Pain Medicine 1999;24:399-404.

\section{Nilsson 1980}

Nilsson E, Lamke O, Liljedahl SO, Elfstrom K. Is albumin therapy worthwhile in surgery for colorectal cancer?. Acta Chir Scand 1980; 146:619-22.

\section{Rehm 2001}

Rehm M, Haller M, Orth V, Kreimeier U, Jacob M, Dressel H, Mayer S, Brechtelsbauer H, Finsterer U. Changes in blood volume and hematocrit during acute preoperative volume loading with $5 \%$ albumin or $6 \%$ hetastarch solutions in patients before radical hysterectomy. Anesthesiology 2001;95(4):849-56.

\section{Steinberg 1989}

Steinberg B, Kochs E, Bause H, Schulte am Esch J. Effects of low molecular weight hydroxyethyl starch (HES 40) in comparison with Ringer solution on oxygen tension in skeletal muscles of infected patients. Anasth Intensivther Notfallmed 1989;24(6):377-81.

Wilkes 2001

Wilkes N, Woolf R, Mutch M, Mallett S, Peache T, Stephens R, Mythen M. The effects of balanced versus saline-based heta-starch and crystalloid solutions on acid-base and electroyte status and gastric mucosal perfusion in elderly sugical patients. Anaesthesia and Analgesia 2001;93(4):811-16.

\section{Woods 1993}

Woods MS, Kelley H. Oncotic pressure, albumin and ileus: the effect of albumin replacement on postoperative ileus. The American Surgeon 1993;59:758-63.

\section{References to studies awaiting assessment}

\section{Bueno R 2004}

Bueno R, Resende AC, Melo R, Neto VA, Stolf NA. Effects of hypertonic saline-dextran solution in cardiac valve surgery with cardiopulmonary bypass. Annals of Thoracic Surgery 2004;77(2):604-11.

\section{Oliviera 2002}

Oliviera RP, Weingartner R, Ribas EO, Moraes RS, Friedman G. Acute haemodynamic effects of a hypertonic saline/dextran solution in stable patients with severe sepsis. Intensive Care Medicine 2002;28 (11):1574-81.

Paul 2003

Paul M, Dueck M, Joachim Herrman H, Holzki J. A randomized, controlled study of fluid management in infants and toddlers during surgery: hydroxyethyl starch 6\% (HES 70/0.5) vs lactated Ringer's solution. Paediatric Anaesthesia 2003;13(7):603-8.

\section{Additional references}

\section{Albumin 2004}

The Albumin Reviewers (Alderson P, Bunn F, Lefebvre C, Li Wan Po A, Li L, Roberts I, Schierhout G). Human albumin solution for resuscitation and volume expansion in critically ill patients (Cochrane Review). The Cochrane Library 2004, Issue 3.Art. No.: CD001208. DOI: .

\section{Armstrong 1994}

Armstrong RF, Bullen C, Cohen SL, Singer M, Webb AR. Critical Care Algorithms. Oxford: Oxford University Press, 1994. 


\section{Bickell 1994}

Bickell WH, Wall MJ, Pepe PE, Martin R, Ginger VF, Allen MK, Mattox KL. Immediate Versus Delayed Resuscitation For Hypotensive Patients With Penetrating Torso Injuries. New England Journal of Medicine 1994;331:1105-9.

Bisonni 1991

Bisonni RS, Holtgrave DR, Lawler F, Marley DS. Colloids versus crystalloids in fluid resuscitation: an analysis of randomized controlled trials. Journal of Family Practice 1991;32(4):387-90.

Fakhry 1995

Fakhry SM, Alexander J, Smith D, Meyer AA, Peterson HD. Regional and institutional variation in burn care. Journal of Burn Care and Rehabilitation 1995;16(1):86-90.

\section{Gosling 1998}

Gosling P. Newer synthetic colloids should not be abandoned. BMJ 1998;317:277.

Oxman 1994

Oxman AD, Cook DJ, Guyatt GH. User's guide to the medical literature. VI. How to use an overview. Journal of the American Medical Association 1994;272:1367-71.

\section{Schulz 1995}

Schulz KF, Chalmers I, Hayes RJ, Altman DG. Dimensions of methodological quality associated with estimates of treatment effects in controlled trials. Journal of the American Medical Association 1995; 273(5):408-12.
Velanovich 1989

Velanovich V. Crystalloid versus colloid fluid resuscitation: a metaanalysis of mortality. Surgery 1989;105(1):65-71.

\section{Vermeulen 1995}

Vermeulen LC, Ratko TA, Erstad BL, Brecher ME, Matuszewski K A. A paradigm for consensus. The University Hospital Consortium guidelines for the use of albumin, nonprotein colloid, and crystalloid solutions. Archives of Internal Medicine 1995;155(4):373-9.

\section{Victorian DUAC 1991}

Subcommittee of the Victorian Drug Usage Advisory Committee. Human albumin solutions: an audit of use in three major metropolitan hospitals. Medical Journal of Australia 1991;154(10):657-60.

Yim 1995

Yim JM, Vermeulen LC, Erstad BL, Matuszewski KA, Burnett DA, Vlasses PH. Albumin and nonprotein colloid solution use in US academic health centers. Archives of Internal Medicine 1995;155(22) $2450-5$.

\section{References to other published versions of this review}

\section{Schierhout 1998}

Schierhout G, Roberts I. Fluid resuscitation with colloids or crystalloid solutions in critically ill patients: a systematic review of randomised controlled trials. BMJ 1998;316:961-4.

* Indicates the major publication for the study

T A B LE S

\section{Characteristics of included studies}

\begin{tabular}{ll} 
Study & Boldt $\mathbf{1 9 8 6}$ \\
\hline Methods & Randomised controlled trial, using sealed opaque envelopes. \\
& $\begin{array}{l}\text { Information on allocation concealment was obtained on contact with the authors. } \\
\text { Blinding and loss to follow-up not mentioned. }\end{array}$ \\
\hline Participants & 55 patients undergoing elective aorto-coronary bypass surgery. \\
& Exclusion criteria were ejection fraction $<50 \%$ and LVEDP $>15 \mathrm{mmHg}$. \\
\hline Interventions & 1) $300 \mathrm{ml} 20 \%$ human albumin solution $(\mathrm{n}=15)$. \\
& 2) $500 \mathrm{ml} 3 \%$ hydroxyethylstarch $(\mathrm{n}=13)$. \\
& 3) $500 \mathrm{ml} 3.5 \%$ gelatine (n= 14). \\
& 4) No colloid (n=13). \\
\hline Outcomes & Haemodynamic variables were measured. \\
& Deaths not reported. \\
\hline Notes & Follow-up until discharge from intensive care. \\
\hline Allocation concealment & B - Unclear \\
\hline & Boldt $\mathbf{1 9 9 3}$ \\
\hline Study & Randomised controlled trial. \\
\hline Methods & Allocation concealment by sealed opaque envelopes (information from author). \\
\hline Colloids versus crystalloids for fluid resuscitation in critically ill patients (Review) \\
Copyright @ 2007 The Cochrane Collaboration. Published by John Wiley \& Sons, Ltd
\end{tabular}




\section{Characteristics of included studies (Continued)}

\begin{tabular}{ll} 
Blinding and loss to follow-up not mentioned. \\
\hline Participants & 75 men undergoing elective aortocoronary bypass grafting, who had a pulmonary capillary wedge pressure \\
& of less than $5 \mathrm{mmHg}$ after induction of anaesthesia. \\
\hline Interventions & 1) $5 \%$ albumin $(\mathrm{n}=15)$. \\
& 2) $6 \% \mathrm{HES}$, mean molecular weight $450,000(\mathrm{n}=15)$. \\
& 3) $6 \% \mathrm{HES}$, mean molecular weight $200,000(\mathrm{n}=15)$. \\
& 4) $3.5 \%$ gelatin $(\mathrm{n}=15)$. \\
& 5) No colloid $(\mathrm{n}=15)$. \\
\hline Futcomes & Deaths not reported, author confirmed there were no deaths. \\
\hline Notes & Follow-up to 1 day. \\
\hline Allocation concealment & B - Unclear \\
\hline
\end{tabular}

\section{Study}

Methods

Participants

Interventions

\section{Boldt 2001}

Randomised controlled trial, using a closed-envelope system. 100 patients undergoing major abdominal surgery.

1) Ringer's lactate $(n=25)$.

2) $6 \%$ HES, mean molecular weight $200 \mathrm{kDa}$, degree of substitution $0.5(\mathrm{n}=25)$.

3) $6 \% \mathrm{HES}$, mean molecular weight $130 \mathrm{kDa}$, degree of substitution $0.4(\mathrm{n}=25)$.

4) $4 \%$ modified fluid gelatin, molecular weight $35 \mathrm{kDA}(\mathrm{n}=25)$.

\begin{tabular}{|c|c|}
\hline Outcomes & $\begin{array}{l}\text { Deaths. } \\
\text { Orthostatic problems. } \\
\text { Haemodynamics and laboratory data. } \\
\text { Fluid input and output. } \\
\text { Costs. }\end{array}$ \\
\hline Notes & Follow-up period unclear. \\
\hline Allocation concealment & B - Unclear \\
\hline Study & Boutros 1979 \\
\hline Methods & $\begin{array}{l}\text { Randomised controlled trial ("randomly divided"). } \\
\text { Method of allocation concealment not described. } \\
\text { Blinding not mentioned. } \\
\text { No loss to follow-up. }\end{array}$ \\
\hline Participants & 24 people undergoing major operative procedures on the abdominal aorta. \\
\hline Interventions & $\begin{array}{l}\text { 1) Albumin in } 5 \% \text { dextrose }(n=7) \text {. } \\
\text { 2) } 5 \% \text { dextrose and Ringer's lactate }(n=8) \text {. } \\
\text { 3) } 5 \% \text { dextrose in } 0.45 \% \text { saline }(n=9) \text {. } \\
\text { Allocated fluids were used on admission to ICU, following surgery, guided by PAWP. Whole blood also given } \\
\text { if clinically needed. }\end{array}$ \\
\hline Outcomes & Deaths reported. \\
\hline Notes & Follow-up to discharge from hospital. \\
\hline Allocation concealment & B - Unclear \\
\hline
\end{tabular}

\section{Study}

Methods

\section{Bowser-Wallace 1986}

Quasi-randomised controlled trial (allocation by alternation).

Blinding not mentioned. 


\section{Characteristics of included studies (Continued)}

\begin{tabular}{|c|c|}
\hline Participants & $\begin{array}{l}\text { Admitted for burns of } 30 \% \text { or more. } \\
\text { Age range } 5 \text { months to } 21 \text { years. } \\
\text { Excluded if already given more than half calculated daily requirement before reaching hospital. }\end{array}$ \\
\hline Interventions & $\begin{array}{l}\text { 1) } 2 \mathrm{ml} / \mathrm{kg} / \% \text { burn Ringer's lactate over } 24 \mathrm{hrs} \text {, then } 0.5 \mathrm{ml} \text { plasmanate } / \mathrm{kg} / \% \text { burn over } 24 \mathrm{hrs} \text { plus } 5 \% \text { dextrose } \\
(\mathrm{n}=19) \text {. } \\
\text { 2) } 2 \mathrm{ml} / \mathrm{kg} / \% \text { burn hypertonic lactated saline over } 24 \mathrm{hrs} \text {, then } 0.6 \mathrm{ml} / \mathrm{kg} / \% \text { burn hypertonic lactated saline } \\
\text { over } 24 \mathrm{hrs} \text { plus oral Haldane's solution. }(\mathrm{n}=19) \\
\text { IV fluids stopped at } 48 \mathrm{hrs}(\mathrm{n}=19) \text {. }\end{array}$ \\
\hline Outcomes & $\begin{array}{l}\text { Deaths reported. } \\
\text { Fluid and electrolytes given, weight, haematocrit. }\end{array}$ \\
\hline$\overline{\text { Notes }}$ & Follow-up to 5 days. \\
\hline ion concealment & na \\
\hline
\end{tabular}

\begin{tabular}{ll} 
Study & Chavez-Negrete $\mathbf{1 9 9 1}$ \\
\hline Methods & Randomised controlled trial (allocation by "random “) numbers"). \\
& Blinding not mentioned. \\
& No loss to follow-up. \\
\hline Participants & Adults admitted to an emergency room with acute gastrointestinal haemorrhage, systolic blood pressure 90 \\
& mmHg or less for up to $1 \mathrm{hr}$ and normal electrocardiograph. \\
& Excluded if pregnant or had renal, cardiac or neurological disease. \\
\hline Interventions & 1) Initial infusion of $250 \mathrm{ml} 7.5 \%$ saline $/ 6 \%$ Dextran 60 given IV (16 patients) or intraosseous (n=10). \\
& 2) Initial IV infusion of $250 \mathrm{ml}$ Ringer's lactate. (n=23) \\
& Resuscitation continued with red cells, $0.9 \%$ saline and Dextran 40 according to clinical judgement. \\
\hline Outcomes & Death. \\
\hline Hotes & Follow-up to 24 hours. \\
\hline Allocation concealment & B - Unclear \\
\hline
\end{tabular}

\begin{tabular}{ll} 
Study & Dawidson $\mathbf{1 9 9 1}$ \\
\hline Methods & Randomised controlled trial (allocation by drawing a card from a deck). \\
& Blinding not mentioned. \\
& No loss to follow-up. \\
\hline Participants & Adults undergoing elective abdominal aortic surgery. \\
& No exclusions mentioned. \\
\hline Interventions & 1)3\% Dextran 70 in Ringer's lactate. $(\mathrm{n}=10)$ \\
& 2) IV Ringer's lactate. ( $\mathrm{n}=10)$ \\
& Fluid used during and for 24 hrs after operation, guided by haemodynamic variables. \\
\hline Outcomes & Death. \\
& Volume transfused, weight change, haemodynamic variables. \\
\hline Notes & Follow-up to discharge from hospital. \\
\hline Allocation concealment & C - Inadequate \\
\hline
\end{tabular}

Study

Dehne 2001

Methods Randomised controlled trial; allocation by sealed envelope assignment.

Colloids versus crystalloids for fluid resuscitation in critically ill patients (Review)

Copyright (c) 2007 The Cochrane Collaboration. Published by John Wiley \& Sons, Ltd 


\section{Characteristics of included studies (Continued)}

Participants 60 male patients (of American Society of Anesthesiologists physical status 1 or 2) scheduled for middle ear surgery.

\begin{tabular}{ll}
\hline Interventions & 1) Lactated Ringer's solution $(\mathrm{n}=15)$. \\
& 2) $6 \%$ HES: molecular weight $200 \mathrm{kD}$, degree of substitiution $0.5(\mathrm{n}=15)$. \\
& 3) $6 \%$ HES: molecular weight $200 \mathrm{kD}$, degree of substitiution $0.60-0.66(\mathrm{n}=15)$. \\
& 4) $6 \%$ HES: molecular weight $450 \mathrm{kD}$, degree of substitiution $0.7(\mathrm{n}=15)$. \\
\hline Outcomes & Deaths not stated but 'all' patients discharged 10-14 days after surgery; therefore no deaths. \\
& Central venous pressure. \\
& Urine output. \\
& Blood osmolality. \\
& Urine osmolality. \\
\hline Notes & Follow-up two days. \\
\hline Allocation concealment & B - Unclear \\
\hline
\end{tabular}

\begin{tabular}{|c|c|}
\hline Study & Eleftheriadis 1995 \\
\hline Methods & $\begin{array}{l}\text { Patients "randomizedly distributed". } \\
\text { Blinding not mentioned. } \\
\text { Unable to assess loss to follow-up. }\end{array}$ \\
\hline Participants & Participants were undergoing coronary artery bypass surgery. \\
\hline Interventions & $\begin{array}{l}\text { 1) } 6 \% \text { hydroxyethylstarch. } \\
\text { 2) } 3.5 \% \text { gelatine. } \\
\text { 3) Ringer's lactate } \\
\text { Allocated fluid was used in the post-operative period only guided by mean arterial pressure. }\end{array}$ \\
\hline Outcomes & $\begin{array}{l}\text { Deaths were not reported. } \\
\text { Haemodynamic variables. }\end{array}$ \\
\hline Notes & Follow-up period unspecified. \\
\hline Allocation concealment & B - Unclear \\
\hline
\end{tabular}

\begin{tabular}{ll} 
Study & Ernest $\mathbf{1 9 9 9}$ \\
\hline Methods & Randomised controlled trial, allocation concealment not described. \\
& $\begin{array}{l}\text { No blinding. } \\
\text { No loss to follow-up mentioned. }\end{array}$ \\
\hline Participants & Patients with a clinical diagnosis of sepsis. \\
\hline Interventions & 1) $5 \%$ albumin $(\mathrm{n}=9)$. \\
& 2) $0.9 \%$ saline $(\mathrm{n}=9)$. \\
& Volume of infusion guided by PAWP. \\
\hline Outcomes & Haemodynamic variables and volume measurements. \\
\hline Deaths not reported. \\
\hline Allocation concealment & B - Unclear \\
\hline
\end{tabular}

\begin{tabular}{ll} 
Study & Evans $\mathbf{1 9 9 6}$ \\
\hline Methods & Quasi-randomised trial (allocation by day of the week). \\
Blinding not mentioned. \\
No loss to follow-up.
\end{tabular}




\section{Characteristics of included studies (Continued)}

\begin{tabular}{ll} 
Participants & $\begin{array}{l}\text { Aged } 16 \text { or more, admitted with trauma to an emergency centre within } 2 \text { hours after injury, only crystalloid } \\
\text { as a pre-hospital infusion. } \\
\text { Excluded if had underlying illness likely to affect clotting. }\end{array}$ \\
\hline Interventions & 1) IV haemaccel $(\mathrm{n}=11)$. \\
& 2) IV Ringer's lactate $(\mathrm{n}=14)$. \\
& Fluid was used until vital signs were stable. \\
\hline Outcomes & Deaths from author. \\
& Clotting variables. \\
\hline Notes & Follow-up period unspecified. \\
\hline Allocation concealment & C - Inadequate
\end{tabular}

\begin{tabular}{ll} 
Study & Gallagher $\mathbf{1 9 8 5}$ \\
\hline Methods & Randomised controlled trial. Method of allocation concealment not described. Author contacted - allocation \\
concealment by computerised system - patient details were entered before treatment assignment was revealed. \\
Blinding not mentioned. \\
No loss to follow-up. \\
\hline Participants & Patients after coronary artery bypass graft surgery. \\
& Exclusions: patients with significant left main coronary artery stenosis, poor left ventricular function or poor \\
& pulmonary function. \\
\hline Interventions & 1) IV 5\% albumin (n=5). \\
& 2) IV 6\% hydroxyethylstarch (n=5) \\
& 3) IV Ringer's lactate (n=5). \\
& Fluid used from admission to intensive care post op, guided by PAWP. RBC given if needed. \\
& Five patients received 5\% albumin. Five patients received lactated Ringer's. \\
\hline Outcomes & Deaths were not reported. Author contacted and confirmed that there were no deaths in any group. \\
& Haemodynamic data. \\
\hline Notes & Follow-up to 1 day. \\
\hline Allocation concealment & A - Adequate \\
\hline
\end{tabular}

\begin{tabular}{|c|c|}
\hline Study & Goodwin 1983 \\
\hline Methods & $\begin{array}{l}\text { Randomised controlled trial - assigned by 'random numbers table'. } \\
\text { Method of allocation concealment unclear. } \\
\text { Blinding not mentioned. } \\
\text { No loss to follow-up. }\end{array}$ \\
\hline Participants & $\begin{array}{l}79 \text { previously healthy young adults admitted with burns. } \\
\text { No exclusion criteria reported. }\end{array}$ \\
\hline Interventions & $\begin{array}{l}\text { 1) } 2.5 \% \text { albumin in Ringer's lactate }(\mathrm{n}=40) \text {. } \\
\text { 2) Ringer's lactate }(\mathrm{n}=39) \text {. } \\
\text { Fluids on day } 1 \text { guided by haemodynamic variable. On day } 2 \text {, given at } 0.3-0.5 \mathrm{ml} / \mathrm{kg} / \% \text { burn, then } 5 \% \\
\text { dextrose. }\end{array}$ \\
\hline Outcomes & $\begin{array}{l}\text { Deaths reported. } \\
\text { Lung water in some. } \\
\text { Infections. }\end{array}$ \\
\hline Notes & Follow-up to discharge from hospital. \\
\hline Allocation concealment & B - Unclear \\
\hline
\end{tabular}




\section{Characteristics of included studies (Continued)}

\begin{tabular}{ll} 
Study & Grundmann $\mathbf{1 9 8 2}$ \\
\hline Methods & Randomised controlled trial. \\
& Method of allocation concealment unclear. \\
& Blinding not mentioned. \\
& No loss to follow-up. \\
\hline Participants & 20 people undergoing partial gastrectomy. \\
& The average age was 50 years (range 19-84). \\
& No exclusion criteria reported. \\
\hline Interventions & 1) Colloid group received human albumin solution. $(\mathrm{n}=14)$. \\
& 2) Details of crystalloid were not reported. (n=6). \\
& Allocated fluid was continued for 4 days after operation. \\
\hline Outcomes & Deaths reported. \\
& Volumes of fluid given. \\
& Haemodynamic variables. \\
\hline Notes & Follow-up to discharge from hospital. \\
\hline Allocation concealment & B - Unclear \\
\hline
\end{tabular}

\begin{tabular}{ll} 
Study & Hall $\mathbf{1 9 7 8}$ \\
\hline Methods & $\begin{array}{l}\text { Quasi-randomised controlled trial (participants were stratified by age, extent of burn and aetiology, and then } \\
\text { allocated by alternation). } \\
\text { Blinding not mentioned. } \\
\text { No loss to follow-up. }\end{array}$ \\
\hline Participants & $\begin{array}{l}\text { Burns covering more than } 10 \% \text { of the body surface (for children), and more than } 15 \% \text { of the body surface } \\
\text { (for adults). }\end{array}$ \\
& No exclusions mentioned. \\
\hline Interventions & 1) $120 \mathrm{ml} / \%$ burn IV $6 \%$ Dextran 70 in $0.9 \%$ saline over 48 hrs plus oral water or IV $5 \%$ dextrose for \\
'metabolic requirements' (n=86). \\
2) $4 \mathrm{ml} / \mathrm{kg} / \%$ burn IV Ringer's lactate over 24 hrs, then $10 \%$ of initial body weight of fluid over 24 hrs plus \\
oral water (n=86). \\
\hline Outcomes \\
Death. \\
\hline Fluid given, haemodynamic variables. \\
\hline Allocation concealment & Collow-up to discharge from hospital. \\
\hline
\end{tabular}

\begin{tabular}{ll} 
Study & Hartmann 1993 \\
\hline Methods & Randomised controlled trial (method of allocation unclear). \\
& Blinding not mentioned. \\
& No loss to Follow-up. \\
\hline Participants & Adults undergoing major abdominal surgery. \\
& Exclusions: cardiorespiratory dysfunction, uraemia, diabetes, taking steroids, anticoagulants or diuretics. \\
\hline Interventions & 1) IV Dextran 70 in saline (concentration not given) with $2.5 \%$ dextrose. ( $\mathrm{n}=15)$. \\
& 2) IV saline (concentration not given) with $2.5 \%$ dextrose. ( $\mathrm{n}=14)$. \\
& $\begin{array}{l}\text { Both groups given red cells, plasma, Dextran } 70 \text { and crystalloids during the operation as decided by the } \\
\text { clinician. Post-operative fluids according to the trial group guided by tissue oxygen tension to the end of } \\
\text { resuscitation. }\end{array}$ \\
\hline Outcomes & Death not reported. \\
& Fluid given, haemodynamic variables. \\
\hline
\end{tabular}




\section{Characteristics of included studies (Continued)}

\begin{tabular}{ll} 
Notes & Follow-up to 7 days. \\
\hline Allocation concealment & B - Unclear \\
\hline Study & Jelenko $\mathbf{1 9 7 8}$ \\
\hline Methods & Randomised controlled trial, method of allocation concealment unclear. \\
& Blinding not mentioned. \\
& No loss to follow-up. \\
\hline Participants & 19 people with burns covering more than 20\% of body surface. \\
\hline Interventions & 1) $12.5 \%$ albumin in hypertonic saline $(240 \mathrm{MeQ}$ Na+, $120 \mathrm{MeQ}$ chloride, $120 \mathrm{MeQ}$ lactate), (n=7). \\
& 2) Hypertonic saline (240MeQ Na+, 120 MeQ chloride, 120 MeQ lactate). (n=5). \\
& 3) Ringer's lactate (n=7). \\
& Allocated fluid was used, guided by haemodynamic variables, to the end of resuscitation. \\
\hline Outcomes & Deaths reported. \\
\hline Hotes & Follow-up to end of resuscitation. \\
\hline Allocation concealment & B - Unclear \\
\hline
\end{tabular}

\begin{tabular}{ll} 
Study & Karanko $\mathbf{1 9 8 7}$ \\
\hline Methods & Randomised controlled trial. Description of allocation procedure unclear. \\
& Blinding not mentioned. \\
& No loss to follow-up. \\
\hline Participants & 32 adult men scheduled for coronary artery bypass surgery. \\
& Exclusions: left ventricular ejection fraction under 40\%, abnormal lung function. \\
\hline Interventions & 1) Colloid group received 6\% dextran 70 ( $\mathrm{n}=14)$. \\
& 2) Ringer's lactate (n=18). \\
& Allocated fluid was used to the end of resuscitation. \\
\hline Outcomes & Deaths reported. \\
& Haemodynamic variables. \\
& Lung water. \\
\hline Notes & Follow-up 2 weeks. \\
\hline Allocation concealment & B - Unclear
\end{tabular}

\begin{tabular}{ll} 
Study & Lang $\mathbf{2 0 0 1}$ \\
\hline Methods & Randomised controlled trial, using a closed-envelope system. \\
\hline Participants & 42 patients scheduled for elective major abdominal surgery. \\
\hline Interventions & 1) Lactated Ringer's $(\mathrm{n}=21)$. \\
& 2) $6 \%$ HES, molecular weight $139 \mathrm{kD}$, degree of substitution $0.4(\mathrm{n}=21)$. \\
\hline Outcomes & Deaths. \\
& Haemodynamics and laboratory data. \\
& Tissue oxygenation. \\
& Voume input and output. \\
\hline Notes & Follow-up period unclear. \\
\hline Allocation concealment & A-Adequate \\
\hline
\end{tabular}

\section{Study}

\section{Ley 1990}

Methods 


\section{Characteristics of included studies (Continued)}

Method of allocation concealment unclear.

Assessment of chest $\mathrm{x}$-ray blinded.

No loss to follow-up.

\begin{tabular}{ll}
\hline Participants & 21 people undergoing coronary artery bypass grafting or valve surgery. \\
\hline Interventions & 1) $6 \%$ hetastarch up to $1.5 \mathrm{~L}$ then $5 \%$ plasma protein fraction $(\mathrm{n}=11)$. \\
& 2) $0.9 \%$ saline $(\mathrm{n}=10)$. \\
& Allocated fluid was used for post-operative fluid resuscitation. \\
\hline Outcomes & Deaths were not reported. \\
& Pulmonary and peripheral oedema. \\
& Haemodynamic variables. \\
\hline Notes & Follow-up to discharge. \\
\hline Allocation concealment & B - Unclear \\
\hline
\end{tabular}

\section{Study}

Methods

Participants

Interventions

\section{Lowe 1977}

Randomised controlled trial, allocation by sealed envelopes.

Blinding not mentioned.

No loss to follow-up.

Participants with serious trauma.

1) $25 \%$ albumin in Ringer's lactate ( $n=77)$.

2) Ringer's lactate $(n=94)$.

Allocated fluid was used throughout the pre- and intra-operative period.

\begin{tabular}{ll}
\hline Outcomes & Deaths reported. \\
\hline Notes & $\begin{array}{l}\text { Follow-up to } 5 \text { days post-operatively. Data on the } 30 \text { participants with chest injuries who were left out of } \\
\text { the Lowe } 1977 \text { report, but included in Moss 1981, have been included in the meta-analysis. }\end{array}$ \\
\hline Allocation concealment & B - Unclear \\
\hline
\end{tabular}

\begin{tabular}{ll} 
Study & Lucas $\mathbf{1 9 7 8}$ \\
\hline Methods & $\begin{array}{l}\text { Randomised controlled trial. } \\
\text { Randomisation was based on the last digit of each patient's case number. }\end{array}$ \\
\hline Participants & 52 seriously injured patients. \\
\hline Interventions & $\begin{array}{l}\text { 1) Standard resuscitation regimen ('balanced electrolyte', blood, fresh frozen plasma) plus salt poor albumin, } \\
\text { maximum } 150 \mathrm{~g} \text { during surgery and } 150 \mathrm{~g} \text { per day for the next } 5 \text { days }(\mathrm{n}=27) . \\
\text { 2) Standard resuscitation regimen as above }(\mathrm{n}=25) .\end{array}$ \\
\hline Outcomes & Deaths reported in some patients. \\
\hline Notes & $\begin{array}{l}\text { In the final report of } 94 \text { randomised patients deaths were not reported. However, in this preliminary report } \\
\text { of } 52 \text { injured patients deaths were reported. }\end{array}$ \\
\hline Allocation concealment & $\mathrm{C}-$ Inadequate \\
\hline
\end{tabular}

\section{Study}

Methods

Participants

\section{Mattox 1991}

Quasi-randomised, allocation by alternation.

Double-blind.

2 patients excluded from the analysis as code of fluid lost.

Participants were pre-hospital trauma victims attended to by emergency personnel within an hour of injury, who had systolic blood pressure of $90 \mathrm{~m} \mathrm{mmHg}$ or less and were 16 years or older. $72 \%$ of participants had sustained penetrating trauma. 


\section{Characteristics of included studies (Continued)}

Interventions

1) $250 \mathrm{~mL}$ Dextran-70 in $7.5 \% \mathrm{NaCl}(\mathrm{n}=211)$.

2) $250 \mathrm{~mL}$ Ringer's lactate, saline or plasmalyte. $(\mathrm{n}=211)$

Allocated fluid was for initial pre-hospital resuscitation only.

\begin{tabular}{ll}
\hline Outcomes & Deaths reported. \\
\hline Notes & Follow-up to hospital discharge or transfer. \\
\hline Allocation concealment & C - Inadequate \\
\hline
\end{tabular}

\begin{tabular}{ll} 
Study & Mazher $\mathbf{1 9 9 8}$ \\
\hline Methods & Patients 'randomized'. \\
& Blinding of care givers by use of pharmacy prepared solutions. \\
& No loss to Follow-up. \\
\hline Participants & Patients undergoing elective coronary artery surgery. \\
& Exclusions: age over 75, ejection fraction under $35 \%$, creatinine over 135 umol/L, ACE inhibitors. \\
\hline Interventions & 1) $5 \mathrm{~mL} / \mathrm{kg}$ polygeline $(\mathrm{n}=10)$. \\
& 2) $5 \mathrm{~mL} / \mathrm{kg} 7.2 \%$ saline $(\mathrm{n}=10)$. \\
& Allocated fluid given post-op over one hour. All patients subsequently receive polygeline and red blood cells. \\
\hline Outcomes & Haemodynamic variables. \\
& Death. \\
\hline Notes & Follow-up to discharge from intensive care. \\
\hline Allocation concealment & B - Unclear \\
\hline
\end{tabular}

\begin{tabular}{|c|c|}
\hline Study & McNulty 1993 \\
\hline Methods & $\begin{array}{l}\text { Randomised controlled trial. Method of allocation concealment not described. } \\
\text { Blinding not mentioned. } \\
\text { No loss to follow-up. }\end{array}$ \\
\hline Participants & Patients following elective cardiopulmonary bypass. \\
\hline Interventions & $\begin{array}{l}\text { 1) } 5 \% \text { albumin and cell-saved blood }(n=14) \text {. } \\
\text { 2) Plasmalyte and cell-saved blood }(n=14) \text {. } \\
\text { Allocated fluid used as part of fluid volume replacement. }\end{array}$ \\
\hline Outcomes & $\begin{array}{l}\text { Deaths not reported. } \\
\text { Study was designed to look at the effect of protein infusion on the accuracy of a haematocrit measuring } \\
\text { device. }\end{array}$ \\
\hline Notes & Length of follow-up unspecified. \\
\hline Allocation concealment & B - Unclear \\
\hline
\end{tabular}

\begin{tabular}{ll} 
Study & Metildi $\mathbf{1 9 8 4}$ \\
\hline Methods & Randomised controlled trial. \\
& Blinding not mentioned. \\
& No loss to follow-up. \\
\hline Participants & Participants were admissions to an intensive care and a trauma unit with adult respiratory distress syndrome \\
& and established pulmonary failure. Included both trauma and non-trauma patients. \\
\hline Interventions & 1) $5 \%$ salt-poor albumin $(\mathrm{n}=20)$. \\
& 2) Ringer's lactate (n=26). \\
& Allocated fluid was used throughout resuscitation, and if an operation was required the allocated fluid was \\
& used for volume replacement before and during the operation. \\
\hline Outcomes & Deaths reported.
\end{tabular}




\section{Characteristics of included studies (Continued)}

\begin{tabular}{|c|c|}
\hline Notes & Follow-up to discharge. \\
\hline Allocation concealment & B - Unclear \\
\hline Study & Modig 1983 \\
\hline Methods & $\begin{array}{l}\text { Quasi-randomised controlled trial, allocation by admission date. } \\
\text { Blinding not mentioned. } \\
\text { No loss to follow-up. }\end{array}$ \\
\hline Participants & $\begin{array}{l}\text { Participants were trauma admissions to an emergency department with a systolic blood pressure of less than } \\
70 \mathrm{mmHg} \text {. Age range was } 20-58 \text { years. }\end{array}$ \\
\hline Interventions & $\begin{array}{l}\text { 1) Dextran-70 in Ringer's lactate }(\mathrm{n}=12) \text {. } \\
\text { 2) Ringer's lactate. }(\mathrm{n}=11) \\
\text { Allocated fluids were given as the initial resuscitation fluid on admission to the emergency department, and } \\
\text { continued as needed until after the 6th day when major reconstructive surgery was undertaken. }\end{array}$ \\
\hline Outcomes & $\begin{array}{l}\text { Deaths reported. } \\
\text { Development of respiratory distress syndrome. }\end{array}$ \\
\hline Notes & Follow-up to definitive reconstructive surgery. \\
\hline Allocation concealment & $\mathrm{C}$ - Inadequate \\
\hline Study & Nagy 1993 \\
\hline Methods & $\begin{array}{l}\text { Randomised controlled trial, contact with author showed it was an open label study. } \\
\text { Blinding not mentioned. } \\
\text { No loss to follow-up. }\end{array}$ \\
\hline Participants & $\begin{array}{l}\text { Participants were adult admissions to a trauma unit, with measurable systolic blood pressure less than } 90 \\
\mathrm{mmHg} \text {. }\end{array}$ \\
\hline Interventions & $\begin{array}{l}\text { 1) Pentastarch in } 0.9 \% \mathrm{NaCl}(\mathrm{n}=21) \text {. } \\
\text { 2) Ringer's lactate }(\mathrm{n}=20) \text {. } \\
\text { Allocated fluid was used throughout resuscitation with the exception that colloid patients recieved a maximum } \\
4 \mathrm{~L} \text { of pentastarch, after which Ringer's lactate was given. }\end{array}$ \\
\hline Outcomes & $\begin{array}{l}\text { Deaths were not reported. } \\
\text { Haemodynamic variables. }\end{array}$ \\
\hline Notes & Follow-up to discharge. \\
\hline Allocation concealment & $\mathrm{C}$ - Inadequate \\
\hline
\end{tabular}

\begin{tabular}{ll} 
Study & Ngo $\mathbf{2 0 0 1}$ \\
\hline Methods & Randomised controlled trial, opaque envelopes containing only treatment pack number. \\
\hline Participants & 230 children with dengue shock syndrome. \\
\hline Interventions & 1) Dextran $70(\mathrm{n}=55)$. \\
& 2) $3 \%$ gelatine $(\mathrm{n}=56)$. \\
& 3) Lactated Ringer's $(\mathrm{n}=55)$. \\
& 4) 'Normal' saline $(\mathrm{n}=56)$. \\
\hline Outcomes & Initial pulse recovery time. \\
& Occurrence of timing and subsequent episodes of shock. \\
& Fall in haematocrit. \\
Volume of fluid administered till recovery. \\
Complications.
\end{tabular}




\section{Characteristics of included studies (Continued)}

And noted that there were no deaths in any group

\begin{tabular}{ll}
\hline Notes & Follow-up period unclear. \\
\hline Allocation concealment & $\mathrm{A}-$ Adequate \\
\hline
\end{tabular}

\section{Study}

Methods

\section{Nielsen 1985}

Randomised controlled trial.

Method of allocation concealment not described.

Blinding not mentioned.

No loss to follow-up.

Participants 26 patients admitted for reconstructive surgery of the abdominal aorta.

Interventions $\quad$ 1) Whole blood, crystalloid plus $80 \mathrm{~g}$ albumin on the day of the operation, and $20 \mathrm{~g}$ per day for the next 3 days. Albumin given as $100 \mathrm{~mL} 20 \%$ human albumin solution. $(\mathrm{n}=13)$

2) Whole blood and crystalloid, type not specified. $(n=13)$

Outcomes Deaths not reported.

Author when contacted confirmed that there were no deaths in either group.

Notes $\quad$ Length of follow-up 4 days.

Allocation concealment $\mathrm{B}$ - Unclear

\begin{tabular}{ll} 
Study & Pockaj $\mathbf{1 9 9 4}$ \\
\hline Methods & Randomised controlled trial, allocation concealment unclear. \\
& Blinding not mentioned. \\
& Loss to Follow-up $18 / 54$ in colloid group, $13 / 53$ in saline group. \\
\hline Participants & Participants required fluid resuscitation as a result of vascular leak syndrome associated with Interleukin-2 \\
& therapy for metastatic cancer. \\
\hline Interventions & 1) $250 \mathrm{~mL}$ boluses of $5 \%$ albumin in saline ( $\mathrm{n}=36$ reported). \\
& 2) $250 \mathrm{~mL}$ boluses of $0.9 \%$ normal saline. ( $\mathrm{n}=40$ reported) \\
& Boluses guided by haemodynamic variables. Both groups also received $0.45 \%$ saline with $10 \mathrm{mmol} / \mathrm{L} \mathrm{KCl.}$ \\
\hline Outcomes & Deaths. \\
& Toxic effects of chemotherapy. \\
& Haemodynamic variables. \\
\hline Notes & B - Unclear \\
\hline Allocation concealment
\end{tabular}

\begin{tabular}{ll} 
Study & Prien $\mathbf{1 9 9 0}$ \\
\hline Methods & Randomised controlled trial. \\
& Blinding not mentioned. \\
& No loss to Follow-up. \\
\hline Participants & Participants were undergoing modified Whipple's operation. \\
\hline Interventions & 1) $10 \%$ hydroxyethyl starch in $0.9 \%$ saline plus plasma protein fraction if requirements $>20 \mathrm{~mL} / \mathrm{kg} .(\mathrm{n}=6)$ \\
& 2) $20 \%$ human albumin solution. $(\mathrm{n}=6)$ \\
& 3) Ringer's lactate. \\
& Allocated fluid was administered intra-operatively only. \\
\hline Outcomes & Deaths. \\
& Intestinal oedema formation. \\
\hline Notes & Follow-up period was unspecifed. \\
\hline Colloids versus crystalloids for fluid resuscitation in critically ill patients (Review) \\
Copyright @ 2007 The Cochrane Collaboration. Published by John Wiley \& Sons, Ltd
\end{tabular}




\section{Characteristics of included studies (Continued)}

Allocation concealment $\mathrm{B}-$ Unclear

\begin{tabular}{ll} 
Study & Rackow $\mathbf{1 9 8 3}$ \\
\hline Methods & Randomised controlled trial, allocation concealment unclear. \\
& Blinding not mentioned. \\
& No loss to follow-up. \\
\hline Participants & $\begin{array}{l}\text { Participants were aged } 54 \text { to } 97 \text {, and had any one of the following pre-determined indicators of shock: systolic } \\
\text { blood pressure of } 90 \mathrm{mmHg} \text { or less, a cardiac index of less than } 2.2 \mathrm{~L} . / \mathrm{min} . \mathrm{m} 2 \text {, a serum arterial lactate greater } \\
\text { than } 18 \mathrm{mg} / \mathrm{dl} \text { and WP less than } 15 \mathrm{mmHg} .\end{array}$ \\
\hline Interventions & 1) $6 \%$ hydroxoethyl starch $(\mathrm{n}=9)$. \\
& 2) $5 \%$ albumin $(\mathrm{n}=9)$. \\
& 3) $0.9 \%$ saline. $(\mathrm{n}=8)$. \\
& Allocated fluid was given as needed until the end of resuscitation. \\
\hline Outcomes & Deaths reported. \\
& Fluid balance. \\
\hline Notes & Follow-up to discharge from hospital. \\
\hline Allocation concealment & B - Unclear
\end{tabular}

\section{Study}

Methods

Participants

Interventions

\section{Rocha e Silva 1994}

Randomised controlled trial.

Participants were admissions to the emergency room, with a systolic blood pressure of $90 \mathrm{mmHg}$ or less and were 16 years of age or older.

Colloid group received 6\% dextran-70 in $7.5 \% \mathrm{NaCl}$; crystalloid group received Ringer's lactate. Allocated fluid was used for the first intravenous infusion only.

Outcomes Death was the main outcome measure, but the data are unpublished.

Notes $\quad$ Follow-up to 30 days. By April 1994, 125 patients had been entered into the study.

Allocation concealment $\mathrm{B}$ - Unclear

Study

Methods

Participants

Interventions

Outcomes

\section{Notes}

Allocation concealment

\section{SAFE 2004}

Randomised controlled trial. Randomisation by minisation algorithm accessed through secure website

Patients aged 18 years and above admitted to closed multidisciplinary intensive care units in 16 tertiary hospitals in Australia over19-month period

1) $4 \%$ albumin (Albumex, CSL) ( $n=3499)$.

2) Normal saline $(n=3501)$

Death.

Pateints with new single or multiple-organ failure.

Mean number of days: in ICU, in hospital, on mechanical ventilation, on renal replacement therapy.

Follow-up to 28 days.

\section{Study}

Methods

\section{Shah 1977}

Randomised controlled trial. Allocation by sealed envelope.

Blinding not mentioned.

No loss to follow-up. 


\section{Characteristics of included studies (Continued)}

\begin{tabular}{ll} 
Participants & $\begin{array}{l}\text { Patients with severe, multiple trauma and a systolic blood pressure of less than 90mmHg. All patients were } \\
\text { adults and both sexes were included. }\end{array}$ \\
\hline Interventions & 1) $5 \%$ salt-poor albumin in Ringer's lactate $(\mathrm{n}=9)$. \\
& 2) Ringer's lactate $(\mathrm{n}=11)$. \\
& Volume infused guided by physiological parameters. \\
\hline Outcomes & Death reported. \\
& Haemodynamic variables. \\
\hline Notes & Length of follow-up not stated. \\
\hline Allocation concealment & B - Unclear
\end{tabular}

\begin{tabular}{ll} 
Study & Shires $\mathbf{1 9 8 3}$ \\
\hline Methods & Patients 'assigned randomly'. \\
& Blinding not mentioned. \\
& No loss to follow-up. \\
\hline Participants & People undergoing aortic reconstruction surgery. \\
& No exclusion criteria mentioned. \\
\hline Interventions & 1) Plasmanate (n=9). \\
& $\begin{array}{l}\text { 2) Ringer's lactate (n=9). } \\
\text { Allocated fluid used guided by haemodynamic variables until the first postoperative morning. All patients } \\
\text { then received 0.45\% saline. }\end{array}$ \\
\hline Outcomes & Lung water. \\
& Haemodynamic variables. \\
& Death. \\
\hline Notes & Follow-up to two days post-op. \\
\hline Allocation concealment & B - Unclear \\
\hline
\end{tabular}

\begin{tabular}{ll} 
Study & Sirieix 1999 \\
\hline Methods & Patients 'randomly assigned'. Blinding not described. \\
& $\begin{array}{l}\text { Two patients excluded after randomisation due to arrhythmias on giving the fluid (both in hypertonic saline } \\
\text { group). }\end{array}$ \\
\hline Participants & Patients undergoing mitral valve repair. \\
& $\begin{array}{l}\text { Exclusions: } \mathrm{LVEF}<0.4 \text {, systolic PAP }>50 \mathrm{mmHg} \text {, coagulation disorders, creatinine }>150 \mathrm{mmoL} / \mathrm{L} \text {, electrolyte } \\
\text { imbalance, diabetes, previous atrial fibrillation lasting }>1 \text { year. }\end{array}$ \\
\hline Interventions & 1) $250 \mathrm{~mL} 7.2 \%$ hypertonic saline, $6 \% \mathrm{HES} \mathrm{(n=8).}$ \\
& 2) $250 \mathrm{~mL} 7.2 \%$ hypertonic saline $(\mathrm{n}=10)$. \\
& 3) $250 \mathrm{~mL} 6 \%$ HES (n=8). \\
& Fluid given over 15 mins, I hour after admission to post-op intensive care \\
\hline Outcomes & Haemodynamic variables. \\
& $\begin{array}{l}\text { Deaths reported. } \\
\text { Side-effects (2 had severe hypotension in group } 2 \text { and } 1 \text { in group 1; arrhythmias in } 1 \text { patient in group 1, 3 } \\
\text { in group } 2 \text { and } 1 \text { in group 3). }\end{array}$ \\
\hline Notes & Follow-up to discharge from hospital (all within 10 days) \\
\hline Allocation concealment & B - Unclear
\end{tabular}

\begin{tabular}{ll} 
Study & Skillman $\mathbf{1 9 7 5}$ \\
\hline Methods & $\begin{array}{l}\text { Randomised controlled trial, allocation concealment unclear. } \\
\text { Blinding not mentioned. }\end{array}$
\end{tabular}




\section{Characteristics of included studies (Continued)}

\begin{tabular}{|c|c|}
\hline Participants & Participants were undergoing elective abdominal reconstructive surgery. \\
\hline Interventions & $\begin{array}{l}\text { 1) } 25 \% \text { salt-poor albumin } 1 \mathrm{~g} / \mathrm{kg} \text { and } 5 \% \text { albumin } 1 \mathrm{~L} .(\mathrm{n}=7) \\
\text { 2) Ringer's lactate. } \\
\text { Allocated fluid was given intra-operatively. All patients received crystalloids only for pre-loading before } \\
\text { surgery. }\end{array}$ \\
\hline Outcomes & Deaths were not reported. \\
\hline \multicolumn{2}{|l|}{ Notes } \\
\hline Allocation concealment & B - Unclear \\
\hline Study & Tollofsrud 1995 \\
\hline Methods & $\begin{array}{l}\text { Randomised controlled trial, allocation by sealed envelopes. } \\
\text { Blinding not mentioned. } \\
\text { No loss to follow-up. }\end{array}$ \\
\hline Participants & $\begin{array}{l}\text { Participants were adult patients in need of volume replacement during and after coronary artery bypass } \\
\text { surgery. }\end{array}$ \\
\hline Interventions & $\begin{array}{l}\text { 1) Haemaccel }(n=10) \\
\text { 2) Dextran } 70(n=10) \\
\text { 3) Albumin } 40(n=10) \\
\text { 4) Ringer's lactate ( } n=10) \text {. } \\
\text { Allocated fluid was used throughout resuscitation. }\end{array}$ \\
\hline Outcomes & $\begin{array}{l}\text { Deaths reported. } \\
\text { Fluid balance. }\end{array}$ \\
\hline Notes & Follow-up to 48 hours. \\
\hline Allocation concealment & B - Unclear \\
\hline
\end{tabular}

\section{Study}

Methods

Participants

Interventions

\section{Tollofsrud 1998}

Randomised controlled trial, allocation by sealed envelope. Described as double blind, no loss to follow-up mentioned.

Patients with three vessel coronary artery disease undergoing elective coronary artery surgery. Exclusions: $\mathrm{LVEF}<0.4$, ventricular aneurysm, significant arrhythmia, diabetes, renal failure, lung disease.

1) $4 \mathrm{~mL} / \mathrm{kg}$ of $75 \mathrm{mg} / \mathrm{mL}$ hypertonic saline in dextran $7060 \mathrm{mg} / \mathrm{mL}$ over $30 \mathrm{mins}(\mathrm{n}=10)$.

2) Same volume and rate of isotonic saline $(n=10)$.

Fluid given just after surgery while still in operating theatre. Ringer's lactate for additional fluid.

\begin{tabular}{ll}
\hline Outcomes & Fluid balance. \\
& $\begin{array}{l}\text { Haemodynamic variables. } \\
\text { Deaths not reported. }\end{array}$ \\
\hline Notes & Follow-up to 48 hours. \\
\hline Allocation concealment & B - Unclear \\
\hline
\end{tabular}

Study

Vassar 1990

Methods

Randomised controlled trial, allocation concealment unclear.

Double blind study (solutions prepared in identical containers).

No loss to follow-up.

Participants Participants were emergency department admissions with trauma and a systolic blood pressure below $80 \mathrm{mmHg}$ and were 18 years or older. 


\section{Characteristics of included studies (Continued)}

Pregnant women and people with preexisting cardiac, hepatic or renal disease were excluded.

\begin{tabular}{ll}
\hline Interventions & 1) $6 \%$ dextran 70 in $7.5 \%$ saline. $(\mathrm{n}=23)$. \\
& 2) Ringer's lactate $(\mathrm{n}=24)$. \\
& $\begin{array}{l}\text { Allocated fluids were given as the initial resuscitation in the emergency department. Additional isotonic } \\
\text { crystalloids (Ringer's lactate) were given as needed. }\end{array}$ \\
\hline Outcomes & Deaths reported. \\
& Haemodynamic variables. \\
\hline Notes & Follow-up to hospital discharge. \\
\hline Allocation concealment & B - Unclear \\
\hline
\end{tabular}

\section{Study}

Methods

Rouble blind study.
No loss to follow-up.

Participants

follow-up.

Participants were pre-hospital trauma cases undergoing helicoptor transport to an emergency centre, with a systolic blood pressure of $100 \mathrm{mmHg}$ or less and were 18 years or older.

Exclusions: preexisting cardiac renal, hepatic or eurological disease. Peripheral oedema.

\section{Vassar 1991}

1) $4.2 \%$ dextran 70 in $7.5 \%$ saline or $6 \%$ dextran 70 in $7.5 \%$ saline. $(n=83)$

2) Ringer's lactate. $(\mathrm{n}=83)$

Fluids were given as the initial resuscitation fluid in the pre-hospital setting. Supplemental isotonic fluids were given at the discretion of the flight nurses.

\begin{tabular}{ll}
\hline Outcomes & $\begin{array}{l}\text { Deaths reported. } \\
\text { Haemodynamic variables }\end{array}$ \\
\hline Notes & $\begin{array}{l}\text { Follow-up to discharge. Allocation was to } 4.2 \% \text { dextran-70; to 6\% dextran-70; or to crystalloid; for the } \\
\text { calculation of the summary effect measure, the two dextran groups are combined. }\end{array}$ \\
\hline Allocation concealment & A-Adequate \\
\hline
\end{tabular}

\begin{tabular}{ll} 
Study & Vassar 1993a \\
\hline Methods & Randomised controlled blind trial, allocation concealed by random sequence of identical containers. \\
& Double blind study. \\
& 36 people excluded post randomisation as deemed not to have met eligibility criteria. \\
& No loss to Follow-up. \\
\hline Participants & Participants, who were undergoing ambulance transport to an emergency centre, had systolic blood pressure \\
& 90 mmHg or less, and were 18 years or older. \\
& Exclusions: asystolic, undergoing CPR, lack sinus complex on ECG, more than 2 hours after trauma, \\
& pregnant, preexisting seizures, bleeding disorder, hepatic, cardiac or renal disease. \\
\hline Interventions & 1) $6 \%$ dextran 70 in $7.5 \%$ saline. (n=89) \\
& 2) $7.5 \%$ saline. (n=85) \\
3) $0.9 \%$ saline (n=84) & Participants received $250 \mathrm{~mL}$ of the allocated fluid in the pre-hospital setting. Additional isotonic crystalloids \\
& were given as needed. \\
\hline Outcomes & Deaths reported. \\
Haemodynamic variables. \\
Trauma scores.
\end{tabular}




\section{Characteristics of included studies (Continued)}

\begin{tabular}{|c|c|}
\hline Study & Vassar 1993b \\
\hline Methods & $\begin{array}{l}\text { Randomised controlled trial, allocation concealed by sequential use of coded identical containers. } \\
\text { Double blind study. } \\
39 / 233 \text { patients excluded as deemed not to meet eligibility criteria, unclear from which groups. }\end{array}$ \\
\hline Participants & $\begin{array}{l}\text { Participants were pre-hospital trauma cases undergoing helicoptor transport to an emergency centre, had a } \\
\text { systolic blood pressure of } 100 \mathrm{mmHg} \text { or less and were } 18 \text { years or older. } \\
\text { Exclusions: asystolic, undergoing CPR, lack sinus complex on ECG, more than } 2 \text { hours after trauma, } \\
\text { pregnant, preexisting seizures, bleeding disorder, hepatic, cardiac or renal disease. }\end{array}$ \\
\hline Interventions & $\begin{array}{l}\text { 1) } 12 \% \text { dextran } 70 \text { in } 7.5 \% \text { saline. }(n=49) \\
\text { 2) } 6 \% \text { dextran } 70 \text { in } 7.5 \% \text { saline. }(n=50) \\
\text { 3) } 7.5 \% \text { saline. }(n=50) \\
\text { 4) Ringer's lactate. }(n=45) \\
\text { Participants received } 250 \mathrm{~mL} \text { of the allocated fluid in the pre-hospital setting. Additional isotonic crystalloids } \\
\text { were given as needed. }\end{array}$ \\
\hline Outcomes & $\begin{array}{l}\text { Deaths reported. } \\
\text { Haemodynamic variables. } \\
\text { Trauma scores and neurological outcome scores. }\end{array}$ \\
\hline Notes & Follow-up to hospital discharge. \\
\hline Allocation concealment & A - Adequate \\
\hline
\end{tabular}

\begin{tabular}{ll} 
Study & Virgilio 1979 \\
\hline Methods & $\begin{array}{l}\text { Allocation 'by random number'. } \\
\text { Blinding not mentioned. } \\
\text { No loss to Follow-up. }\end{array}$ \\
\hline Participants & Participants were undergoing abdominal aortic surgery. \\
\hline Interventions & 1) $5 \%$ albumin. ( $\mathrm{n}=15)$. \\
& 2) Ringer's lactate ( $\mathrm{n}=14)$. \\
& $\begin{array}{l}\text { Allocated fluid was used during operation for maintenence of pre-defined physiological parameters, and the } \\
\text { resuscitation was continued with the allocated fluid until the day following the operation. This was followed } \\
\text { by } 5 \% \text { dextrose in half-normal saline, with potassium chloride as needed. }\end{array}$ \\
\hline Outcomes & Deaths reported. \\
\hline Notes & Follow-up two and a half weeks \\
\hline Allocation concealment & B - Unclear \\
\hline
\end{tabular}

\section{Study}

Methods

Participants

Interventions

\section{Wahba 1996}

Patients 'randomly allocated'.

Blinding not mentioned.

Two patients excluded as they required reoperation for bleeding.

22 adult patients in need of volume replacement following coronary artery bypass surgery.

Exclusions: abnormal left ventricular function, platelet active medication or heparin.

1) Haemaccell $(n=10)$.

2) Ringer's lactate $(\mathrm{n}=10)$.

Allocated fluid was used from the time of admission to intensive care following operation, to the end of resuscitation.

Outcomes Deaths reported.

Pulmonary oedema. 


\section{Characteristics of included studies (Continued)}

Notes

Follow-up to discharge.

Allocation concealment $\mathrm{B}$ - Unclear

Study

Methods

Participants

Interventions

2) albumin $20 \%(300 \mathrm{ml} / 24 \mathrm{~h})(\mathrm{n}=15)$.
3) HES $10 \%(500 \mathrm{ml} / 24 \mathrm{~h})$ for 3 days $(\mathrm{n}=27)$.
Aim was to restore colloid osmotic pressure.

Outcomes Changes in fluid balance, serum albumin, COP and clinical signs of oedema were followed daily. Death rates supplied by the author.

Notes Length of follow-up unspecified.

Allocation concealment $\mathrm{B}-$ Unclear

\begin{tabular}{ll} 
Study & Wu $\mathbf{2 0 0 1}$ \\
\hline Methods & Randomised controlled trial. No details given of randmisation method. \\
\hline Participants & 41 adolescent or adult patients in emergency room suffering from shock. \\
\hline Interventions & $\begin{array}{l}\text { 1) } 4 \% \text { modified fluid gelatin: succinated gelatin } 40 \mathrm{~g} / \mathrm{L} \text {, sodium chloride } 7 \mathrm{~g} / \mathrm{L} \text {, sodium hydroxide } 1.36 \mathrm{~g} / \mathrm{L} \\
(\mathrm{n}=18) . \\
\text { 2) Lactated Ringer's }(\mathrm{n}=16) .\end{array}$ \\
\hline Outcomes & Death \\
& Haemodynamic variables. \\
\hline Notes & Not intention-to-treat: five patients who received blood transfusion and two who had surgery within the first \\
& hour of resuscitation were dropped from the analysis. \\
& Length of follow-up not clear. \\
\hline Allocation concealment & B - Unclear \\
\hline
\end{tabular}

\begin{tabular}{ll} 
Study & Younes $\mathbf{1 9 9 2}$ \\
\hline Methods & Randomised 'in a double blind fashion'. \\
& $\begin{array}{l}\text { Blinding by use of similar bottles. } \\
\text { No loss to follow-up. }\end{array}$ \\
\hline Participants & $\begin{array}{l}\text { Participants were emergency department admissions, who had a systolic blood pressure of less than } 80 \mathrm{mmHg} \\
\text { and were } 19 \text { years and older. }\end{array}$ \\
& Exclusions: pregnant, preexisting cardiac or metabolic disease. \\
\hline Interventions & 1) $6 \%$ dextran 70 in $7.5 \%$ saline $(\mathrm{n}=35)$. \\
& 2) $7.5 \%$ saline ( $\mathrm{n}=35)$. \\
& 3) $0.9 \%$ saline ( $\mathrm{n}=35)$. \\
& Allocated fluid was for initial bolus of 250mL, followed by isotonic crystalloids as needed. \\
\hline Outcomes & Deaths reported. \\
& Fluid balance. \\
\hline Notes & Follow-up to discharge from hospital. \\
\hline Allocation concealment & B - Unclear \\
\hline Colloids versus crystalloids for fluid resuscitation in critically ill patients (Review) \\
Copyright @ 2007 The Cochrane Collaboration. Published by John Wiley \& Sons, Ltd
\end{tabular}




\section{Characteristics of included studies (Continued)}

\begin{tabular}{ll} 
Study & Younes $\mathbf{1 9 9 4}$ \\
\hline Methods & Trial conducted in a 'double blind randomised fashion'. \\
& Blinding by use of coded, identical containers. \\
\hline Participants & $\begin{array}{l}\text { Participants were trauma admissions to the emergency room requiring treatment for haemorrhagic hypo- } \\
\text { volaemia; all were over } 15 \text { years old. } \\
\text { Exclusions: pregnant, cardiac or renal failure, cardiac arrest on arrival. }\end{array}$ \\
\hline Interventions & 1) $6 \%$ dextran 70 in $7.5 \%$ saline $(\mathrm{n}=101)$. \\
& 2) $0.9 \%$ saline. $(\mathrm{n}=111)$ \\
& Allocated fluid was for the first intravenous infusion only. \\
\hline Outcomes & Deaths reported. \\
& Complications. \\
\hline Notes & Follow-up period was 30 days. \\
\hline Allocation concealment & B - Unclear \\
\hline
\end{tabular}

\begin{tabular}{|c|c|}
\hline Study & Younes 1998 \\
\hline Methods & $\begin{array}{l}\text { Randomised controlled trial, allocation by sealed envelope. Blinding not mentioned, no apparent loss to } \\
\text { follow-up. }\end{array}$ \\
\hline Participants & $\begin{array}{l}\text { Trauma patients with systolic blood pressure }<90 \mathrm{mmHg} \text { admitted to the emergency room, with no previous } \\
\text { treatment. }\end{array}$ \\
\hline Interventions & $\begin{array}{l}\text { 1) } 10 \% \text { pentastarch }(\mathrm{n}=12) \text {. } \\
\text { 2) } 0.9 \% \text { saline }(\mathrm{n}=11) \text {. } \\
\text { Fluid given in } 250 \mathrm{~mL} \text { boluses until systolic blood pressure }>100 \mathrm{mmHg}\end{array}$ \\
\hline Outcomes & $\begin{array}{l}\text { Deaths reported. } \\
\text { No complications reported in either group. }\end{array}$ \\
\hline Notes & Follow-up to 24 hours. \\
\hline Allocation concealment & B - Unclear \\
\hline
\end{tabular}

\begin{tabular}{|c|c|}
\hline Study & Zetterstrom 1981a \\
\hline Methods & $\begin{array}{l}\text { The patients were randomly divided into two groups. } \\
\text { Allocation concealment was by sealed opaque envelopes (information supplied by author). } \\
\text { Blinding not mentioned. } \\
\text { No loss to follow-up. }\end{array}$ \\
\hline Participants & Adult patients undergoing elective major abdominal surgery. \\
\hline Interventions & $\begin{array}{l}\text { 1) Standard volume replacement regimen (1L Dextran } 70 \text { then up to } 4 \text { units of RBC with electrolyte, then } \\
\text { whole blood or RBC with plasma; post-op patients were given crystalloids and whole blood) plus } 20 \% \\
\text { human albumin solution } 100 \mathrm{ml} \text { at end of operation, } 200-300 \mathrm{ml} \text { on same day, then } 200 \mathrm{ml} \text { on first post-op } \\
\text { day, then } 100 \mathrm{ml} \text { for next } 3 \text { days }(\mathrm{n}=15) \text {. } \\
\text { 2) Standard volume replacement regimen as above }(\mathrm{n}=15) \text {. }\end{array}$ \\
\hline Outcomes & $\begin{array}{l}\text { Deaths reported. } \\
\text { Haemodynamic variables. }\end{array}$ \\
\hline Notes & Length of follow-up unspecified. \\
\hline llocation concealment & B - Unclear \\
\hline
\end{tabular}

\section{Study Zetterstrom 1981b}

Methods The patients were randomly divided into two groups.

Allocation concealment was by sealed opaque envelopes (information supplied by author). 
Blinding not mentioned.

No loss to follow-up.

\begin{tabular}{|c|c|}
\hline Participants & $\begin{array}{l}18 \text { patients who had undergone elective abdominal aortic surgery. } \\
\text { No exclusions mentioned. }\end{array}$ \\
\hline Interventions & $\begin{array}{l}\text { 1) } 5 \% \text { human albumin solution }(n=9) \text {. } \\
\text { 2) Ringer's lactate solution }(n=9) \text {. } \\
\text { Administration guided by pulmonary arterial occlusion pressure. }\end{array}$ \\
\hline Outcomes & $\begin{array}{l}\text { Deaths reported. } \\
\text { Haemodynamic variables. }\end{array}$ \\
\hline Notes & Follow-up to discharge from hospital. \\
\hline Allocation concealment & B - Unclear \\
\hline $\begin{array}{l}\text { COP = colloid osmotic pre } \\
\text { HES = hydroxyethylstarch } \\
\text { LVEDP = left ventricular e } \\
\text { LVEF = left ventricular ejec } \\
\text { RBC = red blood cells } \\
\text { PAWP = pulmonary artery } \\
\text { PAP = pulmonary artery pr } \\
\mathrm{WP}=\text { wedge pressure }\end{array}$ & $\begin{array}{l}\text { sure } \\
\text { d diastolic pressure } \\
\text { ion fraction } \\
\text { vedge pressure } \\
\text { ssure }\end{array}$ \\
\hline
\end{tabular}

\section{Characteristics of excluded studies}

\begin{tabular}{|c|c|}
\hline Study & Reason for exclusion \\
\hline Artru 1989 & Intervention to control intracranial pressure not directed at fluid resuscitation. \\
\hline Bocanegra 1966 & $\begin{array}{l}\text { This study contained two quasi-randomised comparisons of colloid with glucose and plasma/saline with saline. In } \\
\text { both studies, the control solution was only given IV if the patient was in coma or shock. It was therefore not a } \\
\text { reasonable comparison of colloid and crystalloid. }\end{array}$ \\
\hline Boldt 1996 & All groups received some colloid. \\
\hline Bothner 1998 & Participants were having minor elective surgery, therefore not considered to be critically ill. \\
\hline Breheme 1993 & Intervention directed at haemodilution, not at volume replacement. \\
\hline Golub 1994 & Albumin given solely as a nutritional supplement. \\
\hline Goslinga 1992 & Intervention directed at haemodilution, not volume replacement. \\
\hline Greenhalgh 1995 & Intervention directed at the maintenance of serum albumin levels, not for volume replacement. \\
\hline Hauser 1980 & Cross-over trial. \\
\hline Lagonidis 1995 & Intervention was pre-loading for coronary artery bypass sugery. \\
\hline Marhofer 1999 & Trial of fluid for preloading before spinal anaesthesia. \\
\hline Nilsson 1980 & Albumin given as a nutritional supplement. \\
\hline Rehm 2001 & Two colloids (albumin and hetastarch) compared. \\
\hline Steinberg 1989 & Cross-over trial. \\
\hline Wilkes 2001 & $\begin{array}{l}\text { One group receveived saline plus hetastarch; the other received 'balanced' fluid plus hetatstarch. Thus, each group } \\
\text { received both a colloid and a crystalloid. This conflicts with the purpose our review which compares patients who } \\
\text { had one of these with patients who had the other. }\end{array}$ \\
\hline Woods 1993 & $\begin{array}{l}\text { This quasi-randomised trial looked at albumin supplementation in post operative patients, with the aim of main- } \\
\text { taining the serum albumin. Since the main aim of giving albumin was not to replace volume, the study was ex- } \\
\text { cluded. }\end{array}$ \\
\hline
\end{tabular}


Characteristics of excluded studies (Continued)

A N A L Y S E S

Comparison 01. colloid vs crystalloid (add-on colloid)

\begin{tabular}{|c|c|c|c|c|}
\hline Outcome title & $\begin{array}{l}\text { No. of } \\
\text { studies }\end{array}$ & $\begin{array}{c}\text { No. of } \\
\text { participants }\end{array}$ & Statistical method & Effect size \\
\hline 01 deaths & & & Relative Risk (Fixed) 95\% CI & Subtotals only \\
\hline
\end{tabular}

Comparison 02. colloid and hypertonic crystalloid vs isotonic crystalloid

\begin{tabular}{lcccc} 
Outcome title & $\begin{array}{c}\text { No. of } \\
\text { studies }\end{array}$ & $\begin{array}{c}\text { No. of } \\
\text { participants }\end{array}$ & Statistical method & Effect size \\
\hline 01 deaths & & Relative Risk (Fixed) 95\% CI & Subtotals only \\
\hline
\end{tabular}

Comparison 03. colloid vs hypertonic crystalloid

\begin{tabular}{|c|c|c|c|c|}
\hline Outcome title & $\begin{array}{l}\text { No. of } \\
\text { studies }\end{array}$ & $\begin{array}{c}\text { No. of } \\
\text { participants }\end{array}$ & Statistical method & Effect size \\
\hline 01 deaths & & & Relative Risk (Fixed) 95\% CI & Subtotals only \\
\hline
\end{tabular}

\section{INDEX TERMS}

\section{Medical Subject Headings (MeSH)}

Colloids [ ${ }^{*}$ therapeutic use]; Critical Illness [ ${ }^{*}$ therapy]; Fluid Therapy $\left[{ }^{*}\right.$ methods]; Plasma Substitutes $\left[{ }^{*}\right.$ therapeutic use]; Randomized Controlled Trials; *Rehydration Solutions; Resuscitation [methods]

MeSH check words

Humans

\section{COVER SHEET}

Title

Authors

Contribution of author(s)

Issue protocol first published

Review first published

Date of most recent amendment

Date of most recent

SUBSTANTIVE amendment

What's New

\section{Colloids versus crystalloids for fluid resuscitation in critically ill patients}

Roberts I, Alderson P, Bunn F, Chinnock P, Ker K, Schierhout G

For the first version of this review, all work was by Schierhout and Roberts. The review has been updated in the light of post-publication comments in the British Medical Journal, and the search has been updated with help from Reinhard Wentz of the Cochrane Injuries Group.

For the updated review, Alderson and Roberts examined trials for inclusion or exclusion, reaching agreement by discussion. Alderson and Bunn rechecked all the extracted data from the original review and any new studies. Roberts and Alderson amended the text of the review.

$1997 / 4$

$1997 / 4$

24 August 2005

24 August 2004

August 2004

Six new studies have been included (Boldt 2001; Dehne 2001; Lang 2001; Ngo 2001; SAFE 2004; Wu 2001), and the analysis, results and discussion updated accordingly. 


\section{Date new studies sought but} none found

Date new studies found but not yet included/excluded

Date new studies found and included/excluded

Date authors' conclusions section amended

\section{Contact address}

\section{DOI}

Cochrane Library number

Editorial group

Editorial group code
An updated search for new trials was last conducted in September 2002 (SAFE 2004 was identified separately). The electronic searches will be updated again shortly, to identify any further trials since 2002 .

Information not supplied by author

Information not supplied by author

24 August 2004

Information not supplied by author

Mr Paul Chinnock

Senior Editor

PLoS Medicine

7 Portugal Place

Cambridge

CB5 8AF

UK

E-mail: pchinnock@plos.org

Tel: +44 223463344

10.1002/14651858.CD000567.pub2

CD000567

Cochrane Injuries Group

HM-INJ

GRAPHS ANDOTHER TABLES 


\section{Analysis 0I.0I. Comparison $0 \mathrm{I}$ colloid vs crystalloid (add-on colloid), Outcome $0 \mathrm{I}$ deaths}

Review: Colloids versus crystalloids for fluid resuscitation in critically ill patients

Comparison: 0 I colloid vs crystalloid (add-on colloid)

Outcome: 01 deaths

\begin{tabular}{ccccc} 
colloid & crystalloid & Relative Risk (Fixed) & Weight & Relative Risk (Fixed) \\
$\mathrm{n} / \mathrm{N}$ & $\mathrm{n} / \mathrm{N}$ & $95 \% \mathrm{Cl}$ & $(\%)$ & $95 \% \mathrm{Cl}$ \\
\hline
\end{tabular}

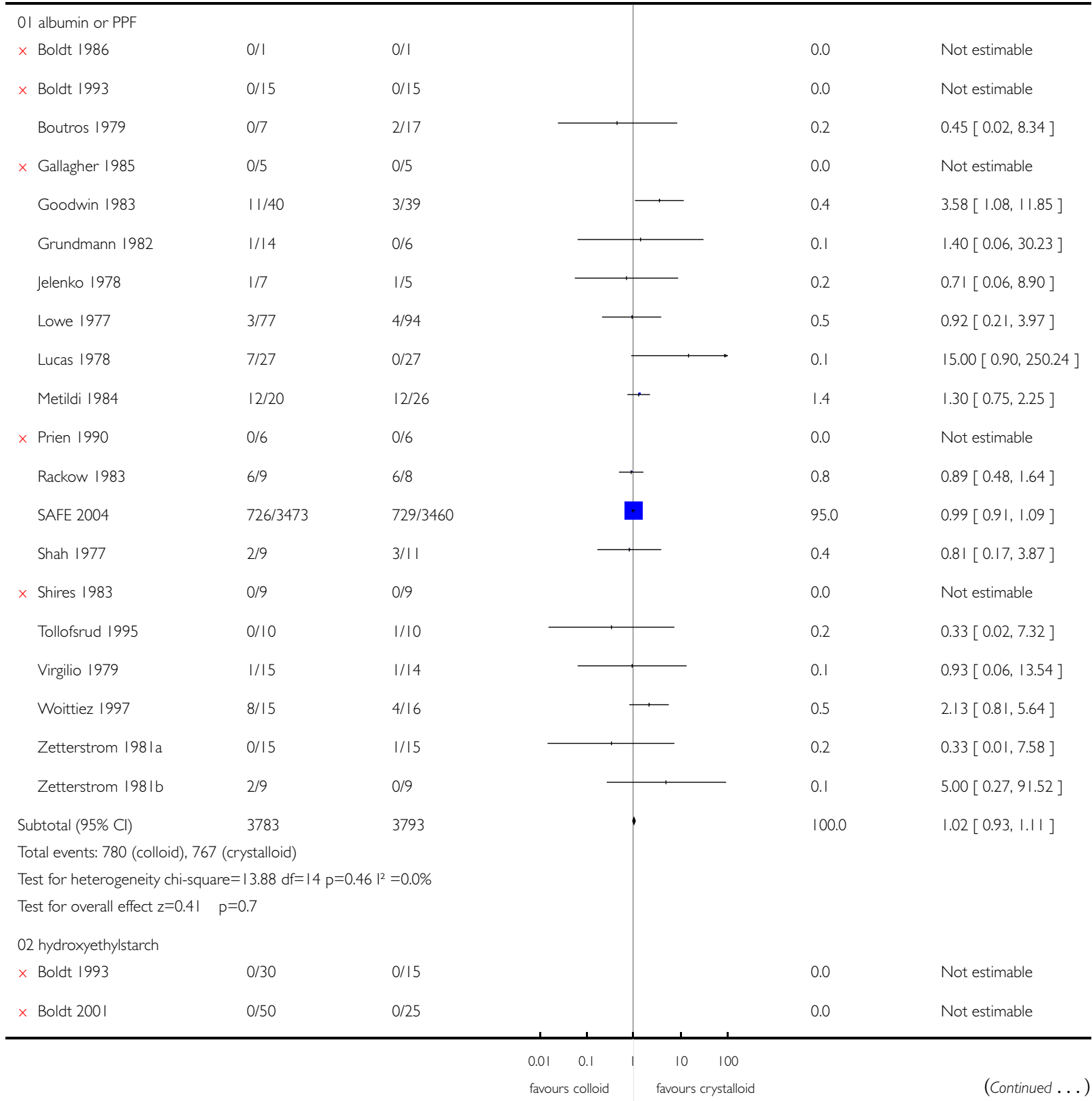

Colloids versus crystalloids for fluid resuscitation in critically ill patients (Review) 
(... Continued)

\begin{tabular}{|c|c|c|c|c|c|}
\hline Study & $\begin{array}{c}\text { colloid } \\
n / N\end{array}$ & $\begin{array}{c}\text { crystalloid } \\
n / N\end{array}$ & $\begin{array}{c}\text { Relative Risk (Fixed) } \\
95 \% \mathrm{Cl}\end{array}$ & $\begin{array}{c}\text { Weight } \\
(\%)\end{array}$ & $\begin{array}{c}\text { Relative Risk (Fixed) } \\
95 \% \mathrm{Cl}\end{array}$ \\
\hline x Dehne 200I & $0 / 45$ & $0 / 15$ & & 0.0 & Not estimable \\
\hline$\times$ Lang 2001 & $0 / 21$ & $0 / 21$ & & 0.0 & Not estimable \\
\hline Nagy 1993 & $2 / 21$ & $2 / 20$ & 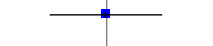 & 12.0 & $0.95[0.15,6.13]$ \\
\hline Prien 1990 & $1 / 6$ & $0 / 6$ & & 2.9 & $3.00[0.15,61.74]$ \\
\hline Rackow 1983 & $5 / 9$ & $6 / 8$ & & 37.2 & $0.74[0.36,1.50]$ \\
\hline$\times$ Sirieix 1999 & $0 / 8$ & $0 / 8$ & & 0.0 & Not estimable \\
\hline Woittiez 1997 & $13 / 27$ & $4 / 16$ & $\because-$ & 29.5 & $1.93[0.76,4.90]$ \\
\hline Younes 1998 & $2 / 12$ & $3 / 11$ & & । 8.4 & $0.61[0.12,3.00]$ \\
\hline Subtotal $(95 \% \mathrm{Cl})$ & 229 & 145 & - & 100.0 & $1.16[0.68,1.96]$ \\
\hline \multicolumn{6}{|c|}{ Total events: 23 (colloid), 15 (crystalloid) } \\
\hline \multicolumn{6}{|c|}{ Test for heterogeneity chi-square $=3.7 \mathrm{ld}=4 \mathrm{p}=0.45 \mathrm{l}^{2}=0.0 \%$} \\
\hline \multicolumn{6}{|c|}{ Test for overall effect $z=0.55 \quad p=0.6$} \\
\hline \multicolumn{6}{|l|}{03 modified gelatin } \\
\hline$\times$ Boldt 1993 & $0 / 15$ & $0 / 15$ & & 0.0 & Not estimable \\
\hline$\times$ Boldt 2001 & $0 / 25$ & $0 / 25$ & & 0.0 & Not estimable \\
\hline Evans 1996 & $1 / 11$ & $2 / 14$ & 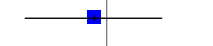 & 27.3 & $0.64[0.07,6.14]$ \\
\hline$\times$ Ngo 2001 & $0 / 56$ & $0 / 111$ & & 0.0 & Not estimable \\
\hline Tollofsrud 1995 & $0 / 10$ & $1 / 10$ & 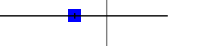 & 23.3 & $0.33[0.02,7.32]$ \\
\hline × Wahba 1996 & $0 / 10$ & $0 / 10$ & & 0.0 & Not estimable \\
\hline Wu 2001 & $2 / 18$ & $3 / 16$ & & 49.4 & $0.59[0.11,3.11]$ \\
\hline Subtotal $(95 \% \mathrm{Cl})$ & 145 & 201 & & 100.0 & $0.54[0.16,1.85]$ \\
\hline \multicolumn{6}{|c|}{ Total events: 3 (colloid), 6 (crystalloid) } \\
\hline \multicolumn{6}{|c|}{ Test for heterogeneity chi-square $=0.13 \mathrm{df}=2 \mathrm{p}=0.94 \mathrm{l}^{2}=0.0 \%$} \\
\hline \multicolumn{6}{|c|}{ Test for overall effect $z=0.98 \quad p=0.3$} \\
\hline \multicolumn{6}{|l|}{04 dextran } \\
\hline Dawidson 1991 & $1 / 10$ & $1 / 10$ & & 1.5 & $1.00[0.07,13.87]$ \\
\hline Hall 1978 & $18 / 86$ & $16 / 86$ & + & 24.7 & $1.13[0.62,2.06]$ \\
\hline Karanko 1987 & $0 / 14$ & $1 / 18$ & & 2.0 & $0.42[0.02,9.64]$ \\
\hline × Modig 1983 & $0 / 14$ & $0 / 17$ & & 0.0 & Not estimable \\
\hline × Ngo 2001 & 0/55 & $0 / 111$ & & 0.0 & Not estimable \\
\hline Tollofsrud 1995 & $0 / 10$ & $1 / 10$ & & 2.3 & $0.33[0.02,7.32]$ \\
\hline Vassar 1993a & $21 / 89$ & $11 / 85$ & - & 17.4 & $1.82[0.94,3.55]$ \\
\hline Vassar 1993b & $49 / 99$ & $20 / 50$ & $=$ & 41.1 & $1.24[0.83,1.83]$ \\
\hline Younes 1992 & $7 / 35$ & $7 / 35$ & $\longrightarrow$ & 10.8 & $1.00[0.39,2.55]$ \\
\hline
\end{tabular}

$\begin{array}{lcccc}0.01 & 0.1 & 1 & 10 & 100 \\ \text { favours colloid } & & \text { favours crystalloid } & (\text { Continued ... })\end{array}$

Colloids versus crystalloids for fluid resuscitation in critically ill patients (Review) 


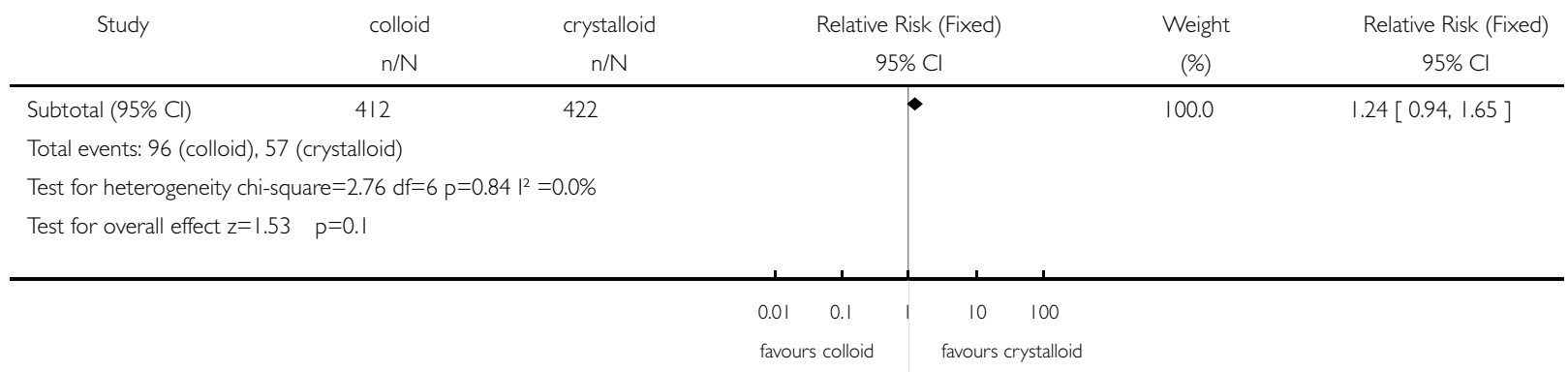

\section{Analysis 02.01. Comparison 02 colloid and hypertonic crystalloid vs isotonic crystalloid, Outcome 01 deaths}

Review: Colloids versus crystalloids for fluid resuscitation in critically ill patients

Comparison: 02 colloid and hypertonic crystalloid vs isotonic crystalloid

Outcome: 01 deaths

\begin{tabular}{|c|c|c|c|c|c|}
\hline Study & $\begin{array}{c}\text { Treatment } \\
n / N\end{array}$ & $\begin{array}{c}\text { Control } \\
\mathrm{n} / \mathrm{N}\end{array}$ & $\begin{array}{c}\text { Relative Risk (Fixed) } \\
95 \% \mathrm{Cl}\end{array}$ & $\begin{array}{c}\text { Weight } \\
(\%)\end{array}$ & $\begin{array}{c}\text { Relative Risk (Fixed) } \\
95 \% \mathrm{Cl}\end{array}$ \\
\hline \multicolumn{6}{|l|}{ OI albumin or PPF } \\
\hline Jelenko 1978 & $1 / 7$ & $2 / 7$ & -1 & 100.0 & $0.50[0.06,4.33]$ \\
\hline Subtotal $(95 \% \mathrm{Cl})$ & 7 & 7 & & 100.0 & $0.50[0.06,4.33]$ \\
\hline \multicolumn{6}{|c|}{ Total events: I (Treatment), 2 (Control) } \\
\hline \multicolumn{6}{|c|}{ Test for heterogeneity: not applicable } \\
\hline \multicolumn{6}{|c|}{ Test for overall effect $z=0.63 \quad p=0.5$} \\
\hline \multicolumn{6}{|l|}{02 hydroxyethylstarch } \\
\hline Subtotal $(95 \% \mathrm{Cl})$ & 0 & 0 & & 0.0 & Not estimable \\
\hline \multicolumn{6}{|c|}{ Total events: 0 (Treatment), 0 (Control) } \\
\hline \multicolumn{6}{|c|}{ Test for heterogeneity: not applicable } \\
\hline \multicolumn{6}{|c|}{ Test for overall effect: not applicable } \\
\hline \multicolumn{6}{|l|}{03 modified gelatin } \\
\hline Subtotal $(95 \% \mathrm{Cl})$ & 0 & 0 & & 0.0 & Not estimable \\
\hline \multicolumn{6}{|c|}{ Total events: 0 (Treatment), 0 (Control) } \\
\hline \multicolumn{6}{|c|}{ Test for heterogeneity: not applicable } \\
\hline \multicolumn{6}{|c|}{ Test for overall effect: not applicable } \\
\hline \multicolumn{6}{|l|}{04 dextran } \\
\hline Chavez-Negrete 1991 & $1 / 26$ & $5 / 23$ & - & 2.9 & $0.18[0.02,1.41]$ \\
\hline Mattox 1991 & $35 / 211$ & $42 / 211$ & 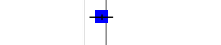 & 22.6 & $0.83[0.56,1.25]$ \\
\hline Vassar 1990 & $12 / 23$ & $13 / 24$ & - & 6.8 & $0.96[0.56,1.65]$ \\
\hline Vassar 199| & $30 / 83$ & $34 / 83$ & $\rightarrow$ & 18.3 & $0.88[0.60,1.30]$ \\
\hline Vassar 1993a & $21 / 89$ & $14 / 84$ & $\longrightarrow$ & 7.7 & $1.42[0.77,2.60]$ \\
\hline Vassar 1993b & $49 / 99$ & $23 / 45$ & 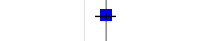 & 17.0 & $0.97[0.68,1.37]$ \\
\hline
\end{tabular}




\begin{tabular}{|c|c|c|c|c|c|}
\hline Study & $\begin{array}{c}\text { Treatment } \\
n / N\end{array}$ & $\begin{array}{c}\text { Control } \\
n / N\end{array}$ & $\begin{array}{c}\text { Relative Risk (Fixed) } \\
\quad 95 \% \mathrm{Cl}\end{array}$ & $\begin{array}{c}\text { Weight } \\
(\%)\end{array}$ & $\begin{array}{c}\text { Relative Risk (Fixed) } \\
95 \% \mathrm{Cl}\end{array}$ \\
\hline Younes 1992 & $7 / 35$ & $8 / 35$ & 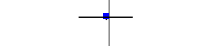 & 4.3 & $0.88[0.36,2.15]$ \\
\hline Younes 1994 & $27 / 101$ & $40 / 111$ & $\Rightarrow$ & 20.5 & $0.74[0.49,1.11]$ \\
\hline Subtotal $(95 \% \mathrm{Cl})$ & 667 & 616 & $\bullet$ & 100.0 & $0.88[0.74,1.05]$ \\
\hline \multicolumn{6}{|c|}{ Total events: 182 (Treatment), 179 (Control) } \\
\hline \multicolumn{6}{|c|}{ Test for heterogeneity chi-square $=5.79 \mathrm{df}=7 \mathrm{p}=0.57 \mathrm{I}^{2}=0.0 \%$} \\
\hline Test for overall effe & & & & & \\
\hline
\end{tabular}

\section{Analysis $\mathbf{0 3 . 0 1}$. Comparison 03 colloid vs hypertonic crystalloid, Outcome $0 \mathrm{I}$ deaths}

Review: Colloids versus crystalloids for fluid resuscitation in critically ill patients

Comparison: 03 colloid vs hypertonic crystalloid

Outcome: 01 deaths

\begin{tabular}{|c|c|c|c|c|c|}
\hline Study & $\begin{array}{c}\text { Treatment } \\
n / N\end{array}$ & $\begin{array}{l}\text { Control } \\
n / N\end{array}$ & $\begin{array}{c}\text { Relative Risk (Fixed) } \\
95 \% \mathrm{Cl}\end{array}$ & $\begin{array}{l}\text { Weight } \\
(\%)\end{array}$ & $\begin{array}{c}\text { Relative Risk (Fixed) } \\
\qquad 95 \% \mathrm{Cl}\end{array}$ \\
\hline \multicolumn{6}{|l|}{01 albumin or PPF } \\
\hline Bowser-Wallace 1986 & $3 / 19$ & $0 / 19$ & & 100.0 & $7.00[0.39,126.92]$ \\
\hline Subtotal $(95 \% \mathrm{Cl})$ & 19 & 19 & & 100.0 & $7.00[0.39,126.92]$ \\
\hline \multicolumn{6}{|c|}{ Total events: 3 (Treatment), 0 (Control) } \\
\hline \multicolumn{6}{|c|}{ Test for heterogeneity: not applicable } \\
\hline \multicolumn{6}{|c|}{ Test for overall effect $z=1.32 \quad p=0.2$} \\
\hline \multicolumn{6}{|l|}{02 hydroxyethylstarch } \\
\hline × Sirieix 1999 & $0 / 8$ & $0 / 8$ & & 0.0 & Not estimable \\
\hline Subtotal $(95 \% \mathrm{Cl})$ & 8 & 8 & & 0.0 & Not estimable \\
\hline \multicolumn{6}{|c|}{ Total events: 0 (Treatment), 0 (Control) } \\
\hline \multicolumn{6}{|c|}{ Test for heterogeneity: not applicable } \\
\hline \multicolumn{6}{|c|}{ Test for overall effect: not applicable } \\
\hline \multicolumn{6}{|l|}{03 modified gelatin } \\
\hline × Mazher 1998 & $0 / 10$ & $0 / 10$ & & 0.0 & Not estimable \\
\hline Subtotal $(95 \% \mathrm{Cl})$ & 10 & 10 & & 0.0 & Not estimable \\
\hline \multicolumn{6}{|c|}{ Total events: 0 (Treatment), 0 (Control) } \\
\hline \multicolumn{6}{|c|}{ Test for heterogeneity: not applicable } \\
\hline \multicolumn{6}{|c|}{ Test for overall effect: not applicable } \\
\hline \multicolumn{6}{|l|}{04 dextran } \\
\hline Subtotal $(95 \% \mathrm{Cl})$ & 0 & 0 & & 0.0 & Not estimable \\
\hline \multicolumn{6}{|c|}{ Total events: 0 (Treatment), 0 (Control) } \\
\hline \multicolumn{6}{|c|}{ Test for heterogeneity: not applicable } \\
\hline Test for overall effect: not ap & & & & & \\
\hline
\end{tabular}

